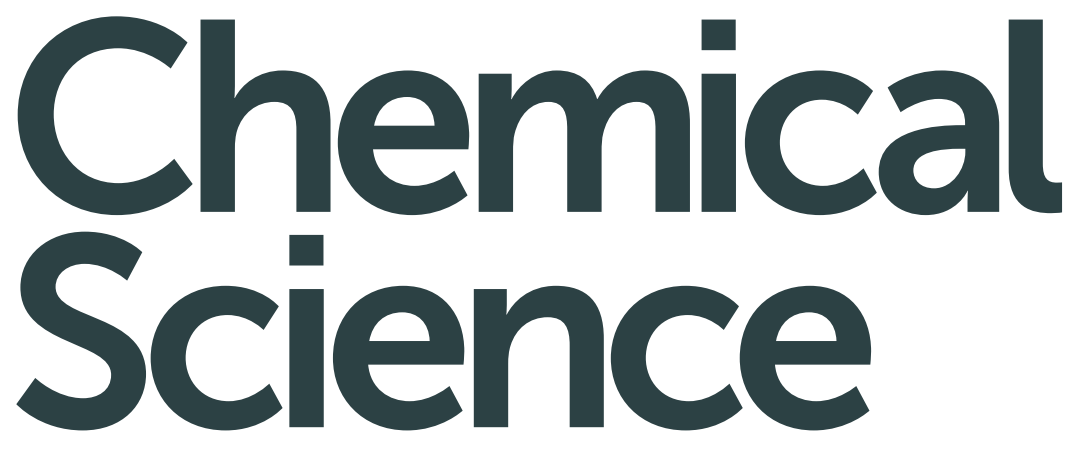

rsc.li/chemical-science

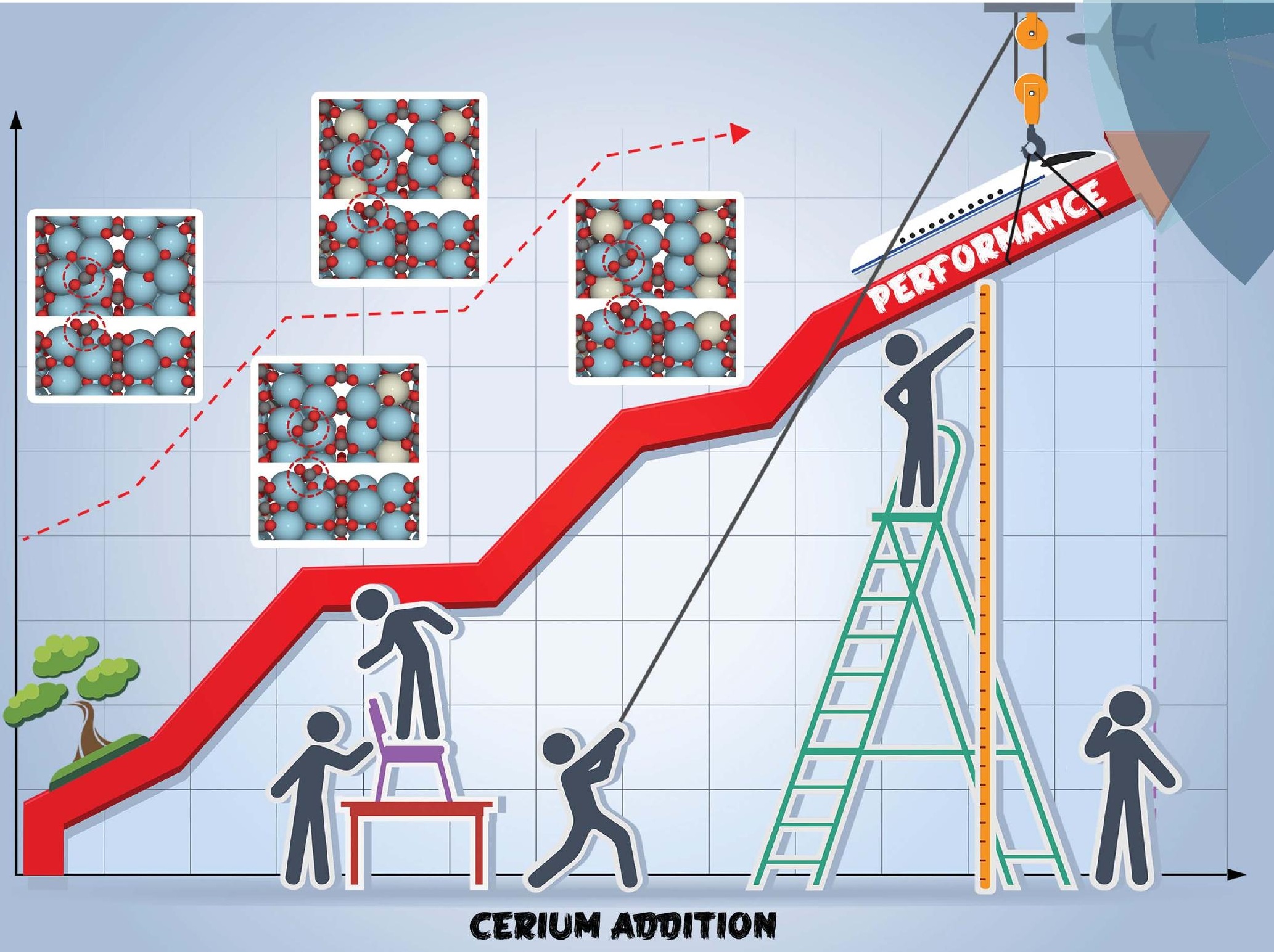

ISSN 2041-6539

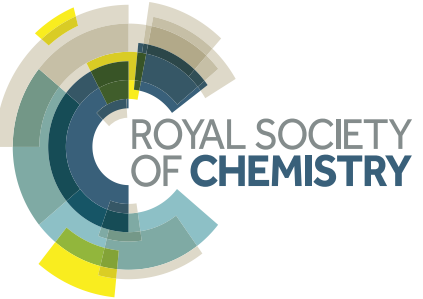


Check for updates

Cite this: Chem. Sci., 2018, 9, 3426

\title{
On the role of $\mathrm{Ce}$ in $\mathrm{CO}_{2}$ adsorption and activation over lanthanum species $\uparrow$
}

\author{
Xinyu Li,,$^{\text {ab }}$ Zhi-Jian Zhao, ta $^{\text {ab }}$ Liang Zeng, $^{\text {ab }}$ Jiubing Zhao, ${ }^{\text {ab }}$ Hao Tian, ${ }^{\text {ab }}$ Sai Chen, ${ }^{\text {ab }}$ \\ Kang Li, ${ }^{\text {ab }}$ Sier Sang ${ }^{\mathrm{ab}}$ and Jinlong Gong (iD *ab
}

$\mathrm{La}_{2} \mathrm{O}_{3}$ exhibits good performance for various catalytic applications, such as oxidative coupling of methane (OCM) and dry reforming of methane (DRM), during which coke formation may lead to the deactivation of catalysts. Typically, the reaction between $\mathrm{CO}_{2}$ adsorbed on $\mathrm{La}_{2} \mathrm{O}_{3}$ and coke is the rate-determining step of the coke elimination process. This paper describes the influence of $\mathrm{Ce}$ addition on the $\mathrm{CO}_{2}$ adsorption and activation over $\mathrm{La}_{2} \mathrm{O}_{3}$. Combined with in situ and ex situ characterization and density functional theory (DFT) calculation, we show that $\mathrm{Ce}$ addition promotes the formation of bidentate carbonate on $\mathrm{La}_{2} \mathrm{O}_{3}$ via tuning $\mathrm{CO}_{2}$ adsorption energy. In addition, $\mathrm{Ce}$ addition adjusts the ratio of bidentate/monodentate carbonate, and affects the ratio of hexagonal/monoclinic $\mathrm{La}_{2} \mathrm{O}_{2} \mathrm{CO}_{3}$ on the binary oxides. DRM is used as a probe reaction to examine the coke elimination performance of $\mathrm{Ce}-\mathrm{La}$ binary oxide. It is found that when the Ce/La ratio reaches the optimal value (0.15), Ce-La binary oxide has the highest $\mathrm{CO}_{2}$ adsorption energy and predominantly promotes the formation of bidentate carbonate, and hence possesses the highest basicity above $700^{\circ} \mathrm{C}$ and finally exhibits the best coke elimination performance.

Received 13th January 2018

Accepted 23rd February 2018

DOI: $10.1039 / \mathrm{c} 8 \mathrm{sc} 00203 \mathrm{~g}$

rsc.li/chemical-science with $\mathrm{La}_{2} \mathrm{O}_{2} \mathrm{CO}_{3}$ increases the basicity of the $\mathrm{La}_{2} \mathrm{O}_{2} \mathrm{CO}_{3}$ material. ${ }^{18}$ In addition, Metiu et al. reported that dopants can affect $\mathrm{CH}_{4}$ activation and dissociation on lanthanum oxide and hence improve the OCM performance. ${ }^{19,20}$

Generally, ceria possesses good redox properties and has various applications. ${ }^{21,22}$ It has been extensively used as an oxygen carrier ${ }^{23}$ and is a necessary component of catalysts used in reforming processes, ${ }^{24-26}$ water-gas shift reaction, ${ }^{27} \mathrm{CO}$ oxidation, ${ }^{28}$ and soot combustion..$^{29,30}$ In order to improve the oxygen storage capacity (OSC) and oxygen mobility (OM) of ceria, an appropriate dopant is typically mixed with ceria to enhance the OSC/OM of ceria. ${ }^{31-33} \mathrm{La}^{3+}$, as an aliovalent dopant, has been extensively applied to enhance the OSC/OM of ceria, ${ }^{34-36}$ during which oxygen vacancies can be formed due to the charge compensation mechanism..$^{37,38}$ It should be noted that the reported synergy of Ce-La binary oxide is based on the fact that La addition can largely promote the formation of oxygen vacancy on ceria, ${ }^{36-38}$ while this paper investigates the influence of Ce addition on the properties of lanthanum species.

Since the release or uptake of lattice oxygen is closely related to an oxygen/steam atmosphere, herein an oxygen/steam atmosphere is excluded to minimize the involvement of oxygen vacancy. Thus, $\mathrm{CO}_{2}$ as a soft oxidant is selected due to its weak oxidation capacity compared with $\mathrm{O}_{2}$ or $\mathrm{H}_{2} \mathrm{O}$ molecule. Given that $\mathrm{CO}_{2}$ adsorbs on the surface of $\mathrm{La}_{2} \mathrm{O}_{3}$ and reacts with $\mathrm{La}_{2} \mathrm{O}_{3}$ to form $\mathrm{La}_{2} \mathrm{O}_{2} \mathrm{CO}_{3},{ }^{5,6}$ the effect of Ce addition on the properties of $\mathrm{La}_{2} \mathrm{O}_{2} \mathrm{CO}_{3}$ formed under the mild oxidative conditions has been investigated. For the OCM reaction, coke
${ }^{a}$ Key Laboratory for Green Chemical Technology of Ministry of Education, School of Chemical Engineering and Technology, Tianjin University, Tianjin 300072, China. E-mail:jlgong@tju.edu.cn

${ }^{b}$ Collaborative Innovation Center of Chemical Science and Engineering (Tianjin), Tianjin 300072, China

$\dagger$ Electronic supplementary information (ESI) available. See DOI: $10.1039 / \mathrm{c} 8 \mathrm{sc} 00203 \mathrm{~g}$

\$ These authors contributed equally to this work. 
deposition is negligible in an oxidative atmosphere, but it takes place under oxygen lean conditions. ${ }^{39,40}$ When $\mathrm{O}_{2}$ is replaced by $\mathrm{CO}_{2}$ to rule out the influence of oxygen vacancy, dry reforming of methane (DRM) mainly occurs, during which $\mathrm{CH}_{4}$ reacts with $\mathrm{CO}_{2}$ to form syngas ( $\mathrm{CO}$ and $\mathrm{H}_{2}$ ). For the DRM reaction, coke deposition and sintering of metal particles can lead to the deactivation of catalysts. ${ }^{\mathbf{4}, \mathbf{4 1}}$ Herein, the DRM reaction is used as a probe reaction to examine the coke elimination performance of Ce-La binary oxides.

This paper demonstrates the influence of Ce addition on the properties of lanthanum species, including the adsorption mode of $\mathrm{CO}_{2}$ (bidentate carbonate and monodentate carbonate) and the crystalline phase of lanthanum oxycarbonate (hexagonal $\mathrm{La}_{2} \mathrm{O}_{2} \mathrm{CO}_{3}$ and monoclinic $\mathrm{La}_{2} \mathrm{O}_{2} \mathrm{CO}_{3}$ ) formed after $\mathrm{CO}_{2}$ and $\mathrm{CH}_{4}$ adsorption. In situ diffuse reflectance infrared Fourier transform spectroscopy (DRIFTS) measurements are applied to investigate surface species on the Ce-La binary oxide during the process of $\mathrm{CO}_{2} / \mathrm{CH}_{4}$ adsorption. The physical-chemical properties of the catalysts prior to and after $\mathrm{CO}_{2} / \mathrm{CH}_{4}$ adsorption are investigated by X-ray diffraction (XRD), X-ray photoelectron spectroscopy (XPS), Raman spectra, $\mathrm{N}_{2}$-physisorption, transmission electron microscopy (TEM), and $\mathrm{H}_{2}$ temperatureprogrammed reduction $\left(\mathrm{H}_{2}-\mathrm{TPR}\right)$. Periodic density functional theory (DFT) calculations are carried out to estimate $\mathrm{CO}_{2}$ adsorption energy on Ce-La binary oxides. DRM is selected as the probe reaction to examine the performance of coke elimination, and $\mathrm{CO}_{2}$ temperature-programmed desorption $\left(\mathrm{CO}_{2}\right.$ TPD) and thermogravimetric analysis (TGA) are applied to examine the basicity of Ce-La binary oxides and properties of the deposited coke during the DRM process.

\section{Results and discussion}

\section{Textural properties of Ce-La binary oxide}

Table 1 sums up the textural properties of the samples with different Ce/La ratios at the moment of "0 min" (Fig. 1, see details in the Experimental section). XRD patterns of a series of Ce-La binary oxides at " 0 min" are shown in Fig. $2 \mathrm{a}$ and $\mathrm{b}$. Hexagonal lanthanum oxycarbonate (II- $\mathrm{La}_{2} \mathrm{O}_{2} \mathrm{CO}_{3}, \mathrm{JCPDF} \# 37-$ 0804) acts as the dominant species for the series of Ce-La binary oxides. When the $\mathrm{Ce} / \mathrm{La}$ ratio reaches 0.10 and higher, monoclinic lanthanum oxycarbonate $\left(\mathrm{Ia}-\mathrm{La}_{2} \mathrm{O}_{2} \mathrm{CO}_{3}\right.$, JCPDF\#481113) can be detected but is minimal. Results show that the

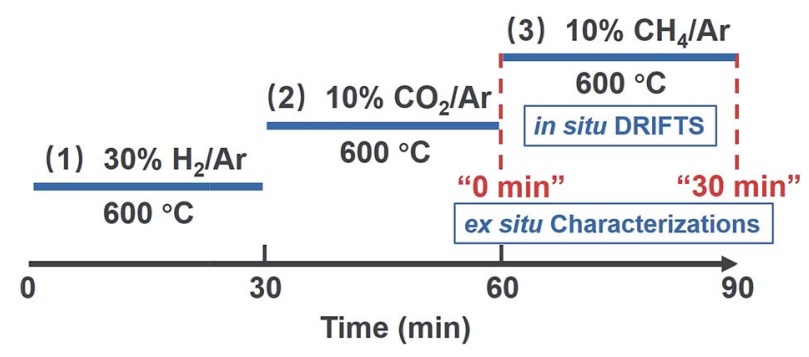

Fig. 1 Overview of the experimental method for in situ and ex situ reaction conditions during measurement.

peaks of $\mathrm{La}_{2} \mathrm{O}_{2} \mathrm{CO}_{3}$ gradually migrate to a higher degree (Fig. 2b), indicating that lattice parameters decrease correspondingly (Table 1$)$. Since the ionic radius of either $\mathrm{Ce}^{3+}(0.101$ $\mathrm{nm})$ or $\mathrm{Ce}^{4+}(0.097 \mathrm{~nm})$ is smaller than that of $\mathrm{La}^{3+}(0.11 \mathrm{~nm}),{ }^{37}$ the decrease of lattice parameters could be attributed to the fact that Ce-ions are doped into the lattice of $\mathrm{La}_{2} \mathrm{O}_{2} \mathrm{CO}_{3} \cdot{ }^{42}$ Furthermore, the surface areas of the series of Ce-La binary oxides were obtained through the $\mathrm{N}_{2}$ sorption isotherm method. With the increase of Ce/La ratios, surface area gradually decreases, which is related to the decrease of lanthanum composition in the binary oxide and the small surface area of the cerium composition. The types of carbonate, formed upon $\mathrm{CO}_{2}$ adsorption, have a close relationship with the crystalline phases of $\mathrm{La}_{2} \mathrm{O}_{2} \mathrm{CO}_{3}$, which will be discussed in the following part.

The valence state of cerium (Fig. 3) and the surface elemental composition (Table 1) were also examined. On the basis of literature reports, ${ }^{\mathbf{4 3 - 4 7}}$ the Ce $3 \mathrm{~d}$ region consists of five doublets. The spin-orbit components with unprimed labels, $v$ and $\mathrm{u}$, are ascribed to the primary Ce $3 \mathrm{~d}_{5 / 2}$ and Ce $3 \mathrm{~d}_{3 / 2}$ states while other doublets represent satellite features arising from the Ce $3 d_{5 / 2}$ and Ce $3 d_{3 / 2}$ ionization. ${ }^{44,46,48}$ The doublets labeled $v_{0} / u_{0}$ and $v^{\prime} / u^{\prime}$ are characteristic of $\mathrm{Ce}^{3+}$, while the remaining doublets labeled $v / u, v^{\prime \prime} / u^{\prime \prime}$ and $v^{\prime \prime \prime} / u^{\prime \prime \prime}$ are characteristic of $\mathrm{Ce}^{4+} \cdot{ }^{44,46}$ The $\mathrm{Ce}^{3+}$ surface concentration was calculated via the following equation: ${ }^{\mathbf{4 4 , 4 8}}$

$$
c_{\mathrm{Ce}^{3+}}=\frac{I\left(v_{0}\right)+I\left(v^{\prime}\right)+I\left(u_{0}\right)+I\left(u^{\prime}\right)}{\sum_{i}\left(I\left(u^{i}\right)+I\left(v^{i}\right)\right)}
$$

where $c_{x}$ denotes the concentration of $x$ and $I(y)$ denotes the integral intensity of the specific peak. It should be noted that

Table 1 Textural properties of the series of Ce-La binary oxide

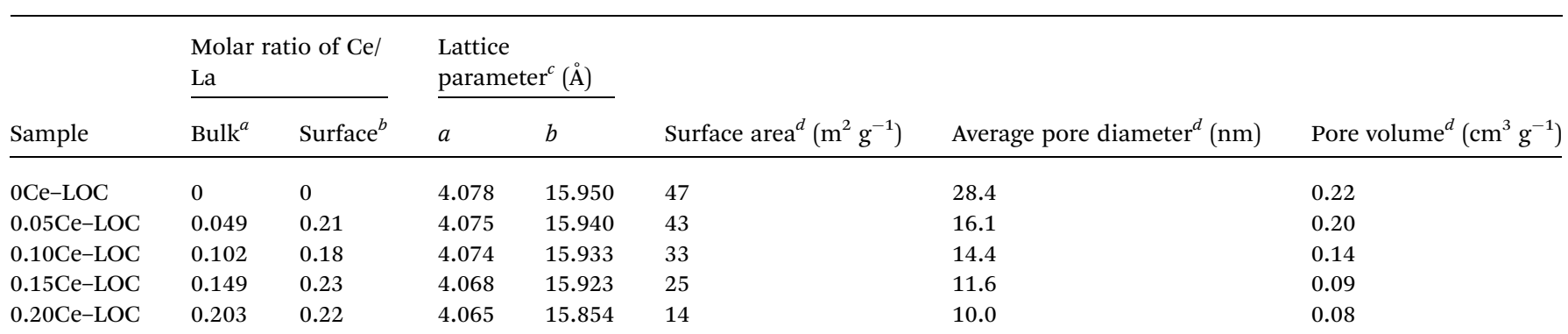

${ }^{a}$ Determined by ICP-OES. ${ }^{b}$ Determined by XPS. ${ }^{c}$ Determined by XRD patterns prior to $\mathrm{CH}_{4}$ adsorption. ${ }^{d}$ Determined by $\mathrm{N}_{2}$-physisorption. 

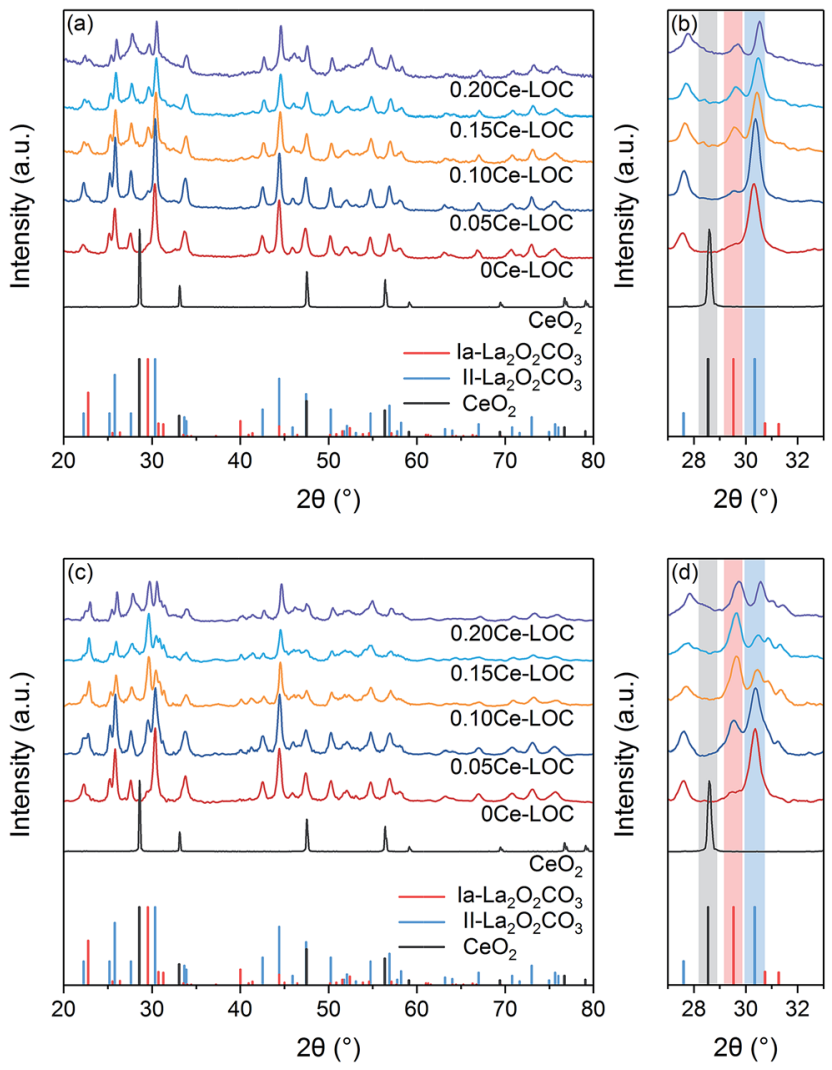

Fig. 2 XRD patterns of the series of $\mathrm{Ce}$-La binary oxide prior to and after $\mathrm{CH}_{4}$ adsorption for 30 min. (a) Full scale at "0 min", (b) details with enlarged scale at " $0 \mathrm{~min}$ ", (c) full scale at "30 min" and (d) details with enlarged scale at "30 min". Color bars in (b) and (d) are auxiliary lines.

the $\mathrm{Ce}^{3+}$ content of $\mathrm{CeO}_{2}$ is $21 \%$ while other Ce-La binary oxides have much higher $\mathrm{Ce}^{3+}$ content than $\mathrm{CeO}_{2}$ (Fig. 3). It is assumed that the enhanced content of $\mathrm{Ce}^{3+}$ is doped into the lattice of $\mathrm{La}_{2} \mathrm{O}_{2} \mathrm{CO}_{3}$ to maintain the concentration of $\mathrm{Ce}^{3+}$, which is consistent with the reduced lattice parameter. As the Ce/La ratio increases from 0.05 to 0.20 , the $\mathrm{Ce}^{3+}$ content gradually decreases (Fig. 3), indicating that the trend to be doped into the lattice of $\mathrm{La}_{2} \mathrm{O}_{2} \mathrm{CO}_{3}$ is close to saturated state and $\mathrm{Ce}^{4+}$ might exist in the form of $\mathrm{CeO}_{2}$ distributed on the surface of the binary oxide. Additionally, $\mathrm{CeO}_{2}$ diffraction peaks are absent even in the enlarged graph of XRD patterns (Fig. 2b), which suggests that $\mathrm{CeO}_{2}$ particles are uniformly dispersed on the surface of the CeLa binary oxide. For the series of Ce-La binary oxides (Table 1), bulk Ce/La ratios obtained from ICP-OES were consistent with nominal $\mathrm{Ce} / \mathrm{La}$ ratios, while surface $\mathrm{Ce} / \mathrm{La}$ ratios obtained from XPS are higher than bulk Ce/La ratios. The difference in Ce/La ratios between the bulk and surface mainly results from the selected subsequent impregnation method, namely $\mathrm{La}_{2} \mathrm{O}_{2} \mathrm{CO}_{3}$ was first synthesized and then impregnated with Ce precursor solution so that cerium mainly distributed on the surface of the binary oxide.

The morphology and structure of Ce-La binary oxides with different Ce/La ratios were characterized via TEM (Fig. S1 in the ESI $\dagger$ ). Particles randomly distribute along the surface of $\mathrm{La}_{2} \mathrm{O}_{2} \mathrm{CO}_{3}$, and some of them are confirmed as $\mathrm{CeO}_{2}$. It can be found that small particles have continuous lattice fringes with the oxide hosts, indicating the formation of the solid solution on the interface between the observed small particles and oxide hosts. ${ }^{37}$ Since $\mathrm{CeO}_{2}$ diffraction peaks are absent in XRD patterns (Fig. 2), UV-vis is applied to measure the indirect band gap of $\mathrm{CeO}_{2}$, which reflects variation tendency in the size of $\mathrm{CeO}_{2}$ particles located on the surface of the samples. ${ }^{\mathbf{4 9 , 5 0}}$ The indirect band gaps of nonoriented polycrystalline $\mathrm{CeO}_{2}$ and $\mathrm{La}_{2} \mathrm{O}_{3}$ are $3.19 \mathrm{eV},{ }^{49}$ and $5.2 \mathrm{eV},{ }^{51}$ respectively. As shown in Fig. $\mathrm{S} 2$ in the ESI, $\uparrow$ the indirect band gap of $\mathrm{CeO}_{2}$ migrates to a lower value with the increase of $\mathrm{Ce} / \mathrm{La}$ ratios, indicating the corresponding increment in the size of $\mathrm{CeO}_{2}$ particles on the surface of binary oxides. In addition, the variation tendency of the increment remains the same when the Ce/La ratio reaches 0.15 and 0.20 . It is reported that the concentration of $\mathrm{Ce}^{3+}$ increases with the reduction in $\mathrm{CeO}_{2}$ particle size. ${ }^{47}$ Therefore, the obtained results of UV-vis (Fig. S2 in the ESI $\dagger$ ) have a similar variation tendency with the results of XPS (Fig. 3).
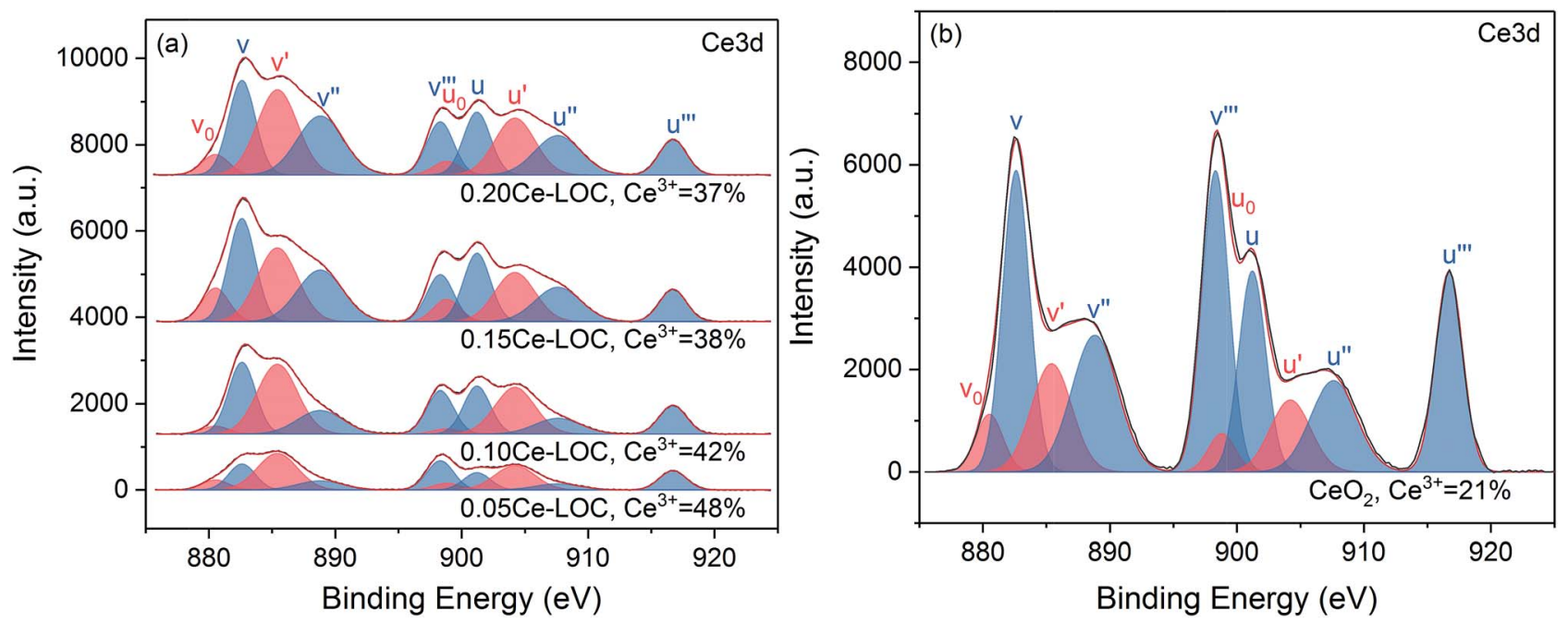

Fig. 3 Fitting of core-level Ce 3d XPS profiles of (a) the series of Ce-La binary oxide and (b) $\mathrm{CeO}_{2}$. 


\section{In situ DRIFTS measurements}

In situ DRIFTS measurements are applied in order to identify surface intermediates present on the Ce-La binary oxide samples from "0 min" to "30 min" (see the definition in the Experimental section), during which coke is formed via $\mathrm{CH}_{4}$ decomposition and will further react with carbonate formed after $\mathrm{CO}_{2}$ adsorption (Fig. 1). In situ DRIFTS spectra are shown in Fig. 4, and corresponding contour graphs are inserted in the $x-y$ planes of Fig. 4 and listed alone in Fig. S3 in the ESI. $\dagger$ The band at $1300 \mathrm{~cm}^{-1}$ corresponds to the $\mathrm{C}-\mathrm{H}$ bending of gaseous methane, ${ }^{24,52,53}$ and it can be found on all samples. The strong band at $1563 \mathrm{~cm}^{-1}$ corresponds to bidentate carbonate with the coexistence of bands at 1300, 1029 and $856 \mathrm{~cm}^{-1,15,54,55}$ while the strong band at $1345 \mathrm{~cm}^{-1}$ is ascribed to monodentate carbonate with the coexistence of bands at 1428, 1070 and $856 \mathrm{~cm}^{-1} \mathbf{.}^{\mathbf{1 5 , 5 4 , 5 5}}$ In addition, bands at 1748 and $1796 \mathrm{~cm}^{-1}$ are overtones of $\mathrm{C}=\mathrm{O}$ stretching vibration and $\mathrm{CO}_{3}{ }^{2-}$ stretching vibration. ${ }^{15}$

For the series of La-Ce binary oxides, both bidentate carbonate and monodentate carbonate exist on the surface (Fig. 4 and $\mathrm{S} 3$ in the $\mathrm{ESI}^{\dagger}$ ), while for $\mathrm{CeO}_{2}$, bidentate carbonate is absent (Fig. $4 \mathrm{f}$ and S3f in the ESI $\dagger$ ). At " 0 min", the intensity of bidentate carbonate on La-Ce binary oxides increases as the Ce/ La ratio increases from 0 to 0.15 , reaches the maximum when the $\mathrm{Ce} / \mathrm{La}$ ratio is $\mathbf{0 . 1 5}$, and finally decreases slightly when the $\mathrm{Ce} / \mathrm{La}$ ratio reaches 0.20 (Fig. S3 and S4 in the ESI $\dagger$ ).
Simultaneously, the intensity of monodentate carbonate shows a variation tendency, which is opposite to the intensity of bidentate carbonate. Therefore, it is assumed that Ce addition can influence the $\mathrm{CO}_{2}$ adsorption mode on the surface of $\mathrm{Ce}-\mathrm{La}$ binary oxide and promote the transformation from monodentate carbonate to bidentate carbonate.

When $\mathrm{CO}_{2}$ is adsorbed on $\mathrm{La}_{2} \mathrm{O}_{3}$ (30 min prior to " $0 \mathrm{~min}$ " in Fig. 1), it reacts with $\mathrm{La}_{2} \mathrm{O}_{3}$ and then leads to the formation of $\mathrm{La}_{2} \mathrm{O}_{2} \mathrm{CO}_{3}$. During the in situ DRIFTS measurement (from " 0 min" to "30 min" in Fig. 1), $\mathrm{CH}_{4}$ can be adsorbed on the surfaces of $\mathrm{La}_{2} \mathrm{O}_{2} \mathrm{CO}_{3}$ and dissociates to form coke under non-oxidative conditions, ${ }^{39,40}$ while coke will react with $\mathrm{La}_{2} \mathrm{O}_{2} \mathrm{CO}_{3}$ to form $\mathrm{La}_{2} \mathrm{O}_{3}$ and CO.,8 ${ }^{5,8}$ or the series of Ce-La binary oxides, the intensity of bidentate carbonate keeps decreasing as time on stream goes by, while the intensity of monodentate carbonate remains stable (Fig. 5 and S3 in the ESI $\dagger$ ). Therefore, bidentate carbonate is consumed to react with coke during the introduction of $\mathrm{CH}_{4}$. It is concluded that bidentate carbonate is active in the reaction with the coke, while monodentate carbonate is inactive (Fig. 4, S3 and S4 in the ESI $\dagger$ ). If we use $I_{\mathrm{B}} /$ $I_{\mathrm{M}}$ (intensity of $\sim 1563 \mathrm{~cm}^{-1} /$ intensity of $\sim 1345 \mathrm{~cm}^{-1}$ ) to evaluate the ratio of bidentate carbonate to monodentate carbonate, it is found that when the Ce/La ratio equals 0.15 , CeLa binary oxide possesses the highest ratio of $I_{\mathrm{B}} / I_{\mathrm{M}}$ (Fig. 5). Considering that Ce addition can affect the ratio of $I_{\mathrm{B}} / I_{\mathrm{M}}$, it is
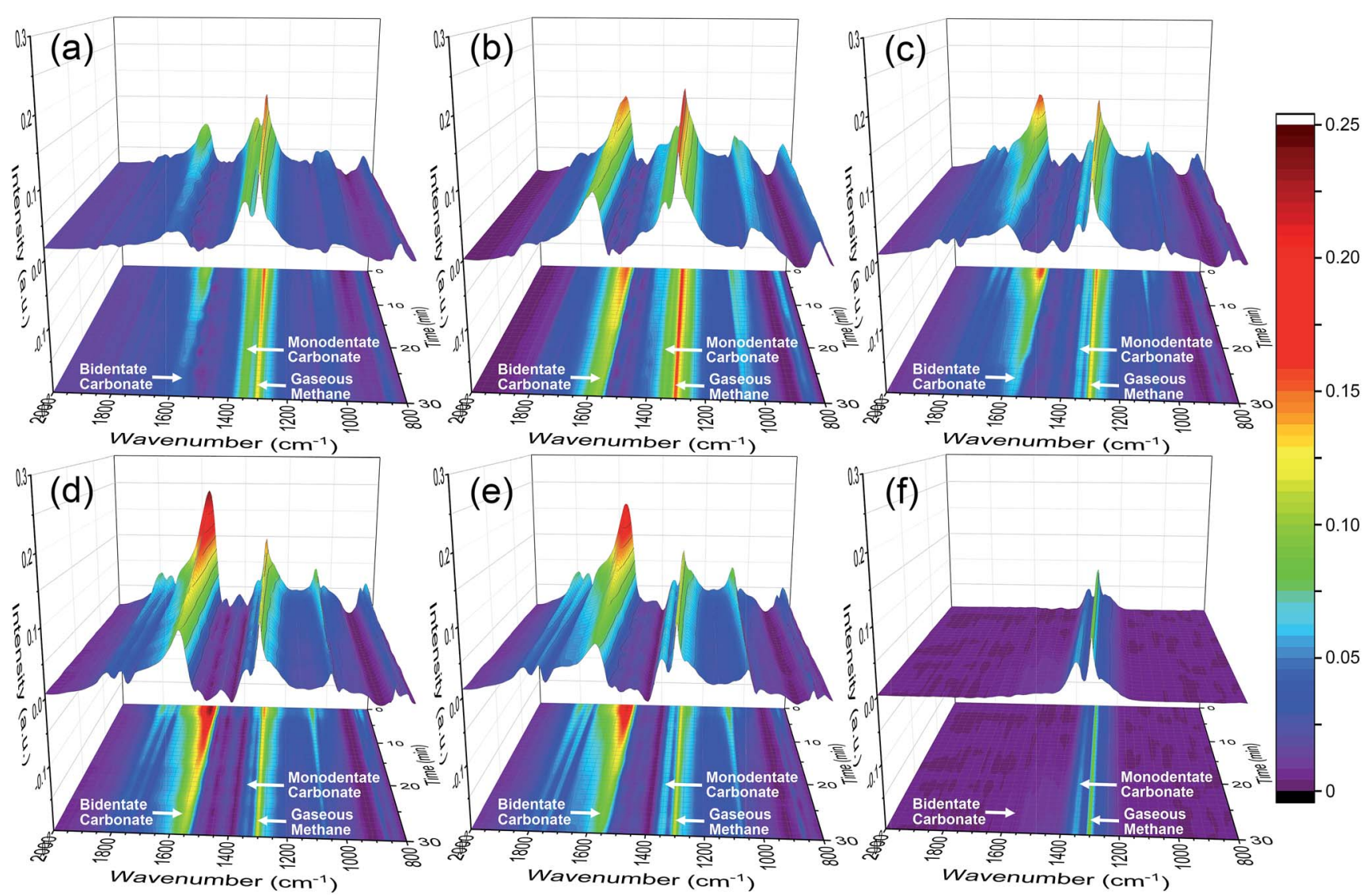

Fig. 4 DRIFTS spectra for the series of $\mathrm{Ce}$-La binary oxide during $\mathrm{CH}_{4}$ adsorption for 30 min. (a) $0 \mathrm{Ce}-\mathrm{LOC}$, (b) $0.05 \mathrm{Ce}-\mathrm{LOC}$, (c) $0.10 \mathrm{Ce}-\mathrm{LOC}$, (d) $0.15 \mathrm{Ce}-\mathrm{LOC}$, (e) $0.20 \mathrm{Ce}-\mathrm{LOC}$ and (f) $\mathrm{CeO}_{2}$. 


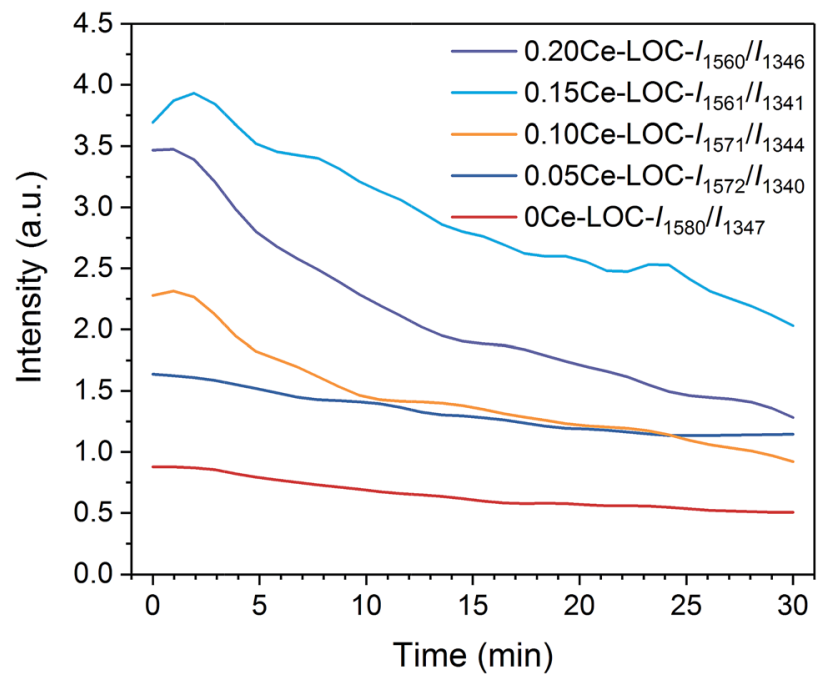

Fig. 5 The intensity ratios of bidentate/monodentate carbonate in DRIFTS spectra as a function of time on stream.

assumed that Ce addition might affect the performance of coke elimination, which will be discussed in the following part.

\section{Influence on the crystalline phase}

XRD patterns of the series of Ce-La binary oxides at " $30 \mathrm{~min}$ " after reacting with $\mathrm{CH}_{4}$ are shown in Fig. 2c and d. The $\mathrm{CeO}_{2}$ phase remains absent indicating that cerium is well dispersed. By comparison of the XRD patterns of samples at " 0 min" and "30 min", the intensity of peaks ascribed to $\mathrm{II}-\mathrm{La}_{2} \mathrm{O}_{2} \mathrm{CO}_{3}$ decreases significantly compared with Ia- $\mathrm{La}_{2} \mathrm{O}_{2} \mathrm{CO}_{3}$. In addition, it is observed that as the $\mathrm{Ce} / \mathrm{La}$ ratio increases from 0 to 0.15 , the decrease in the intensity of $\mathrm{II}^{-} \mathrm{La}_{2} \mathrm{O}_{2} \mathrm{CO}_{3}$ peaks becomes much more prominent. The consumption of II$\mathrm{La}_{2} \mathrm{O}_{2} \mathrm{CO}_{3}$ during the $\mathrm{CH}_{4}$ adsorption indicates that II- $\mathrm{La}_{2} \mathrm{O}_{2} \mathrm{CO}_{3}$ is more active than Ia- $\mathrm{La}_{2} \mathrm{O}_{2} \mathrm{CO}_{3}$ for coke elimination. For the $0.15 \mathrm{Ce}-\mathrm{LOC}$ sample, the intensity of II- $\mathrm{La}_{2} \mathrm{O}_{2} \mathrm{CO}_{3}$ is much lower than that of $\mathrm{Ia}^{-} \mathrm{La}_{2} \mathrm{O}_{2} \mathrm{CO}_{3}$ so that $\mathrm{Ia}-\mathrm{La}_{2} \mathrm{O}_{2} \mathrm{CO}_{3}$ eventually becomes the dominant species on the sample, indicating that $\mathrm{Ce}$ addition can influence the decomposition of $\mathrm{II}-\mathrm{La}_{2} \mathrm{O}_{2} \mathrm{CO}_{3}$ caused by the reaction with deposited coke.

Raman spectra of samples at "30 min" are shown in Fig. 6, which are consistent with the XRD patterns. Peaks at 290, 333, $438,451,1052$, and $1341 \mathrm{~cm}^{-1}$ correspond to $\mathrm{Ia}-\mathrm{La}_{2} \mathrm{O}_{2} \mathrm{CO}_{3}$, while peaks at $355,385,740$, and $1082 \mathrm{~cm}^{-1}$ are assigned to II$\mathrm{La}_{2} \mathrm{O}_{2} \mathrm{CO}_{3} \cdot{ }^{13,56,57}$ The intensity ratio of peaks at $355 \mathrm{~cm}^{-1}$ / $451 \mathrm{~cm}^{-1}$ can be used as a descriptor to evaluate the dominant surface species. When the Ce/La ratios are 0 and 0.05 , the II$\mathrm{La}_{2} \mathrm{O}_{2} \mathrm{CO}_{3}$ phase is the dominant surface species and Ia$\mathrm{La}_{2} \mathrm{O}_{2} \mathrm{CO}_{3}$ phase is the subordinate. However, when the $\mathrm{Ce} / \mathrm{La}$ ratio is higher than 0.10 , Ia- $\mathrm{La}_{2} \mathrm{O}_{2} \mathrm{CO}_{3}$ acts as the dominant surface species. For $0.15 \mathrm{Ce}-\mathrm{LOC}$, it possesses the lowest intensity ratio of peaks at $355 \mathrm{~cm}^{-1} / 451 \mathrm{~cm}^{-1}$, indicating that the ratio of II- $\mathrm{La}_{2} \mathrm{O}_{2} \mathrm{CO}_{3} / \mathrm{Ia}-\mathrm{La}_{2} \mathrm{O}_{2} \mathrm{CO}_{3}$ reaches the lowest level. It can be assumed that II- $\mathrm{La}_{2} \mathrm{O}_{2} \mathrm{CO}_{3}$ formed on the $0.15 \mathrm{Ce}-\mathrm{LOC}$ sample has the fastest decomposition rate. Two additional

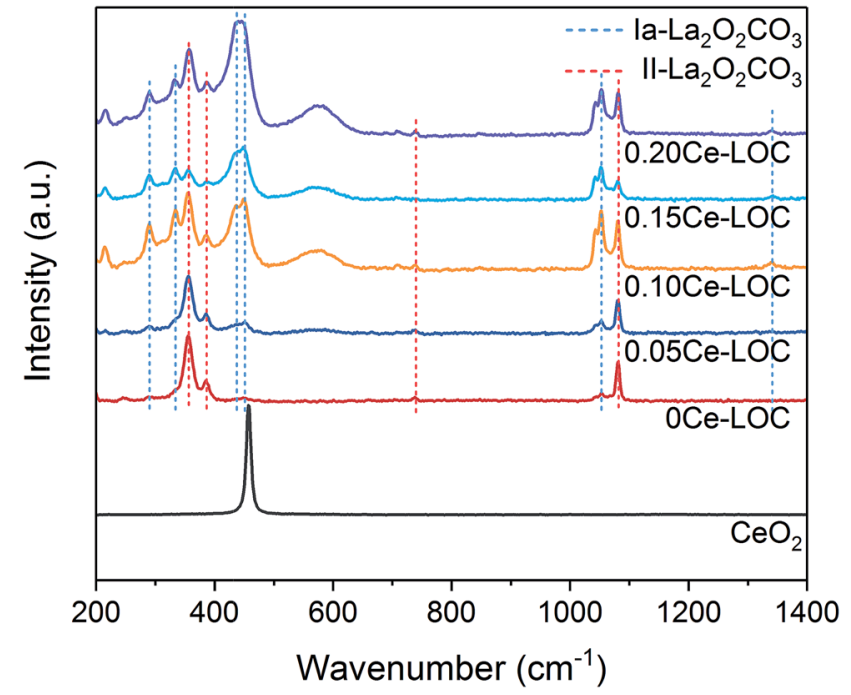

Fig. 6 Raman spectra of the series of $\mathrm{Ce}-\mathrm{La}$ binary oxide upon $\mathrm{CH}_{4}$ adsorption for $30 \mathrm{~min}$.

peaks at 216 and $577 \mathrm{~cm}^{-1}$ are reported to be induced by the dopant, ${ }^{58}$ which verifies the existence of $\mathrm{Ce}^{3+}$ in the lattices of the samples. ${ }^{\mathbf{5 9 , 6 0}}$

DRIFTS results demonstrate that Ce addition is capable of facilitating the formation of bidentate carbonate, which is active for coke elimination. Based on the XRD patterns (Fig. 2) and Raman spectra (Fig. 6), with the decomposition of bidentate carbonate, the ratio of II- $\mathrm{La}_{2} \mathrm{O}_{2} \mathrm{CO}_{3}$ to $\mathrm{Ia}^{-} \mathrm{La}_{2} \mathrm{O}_{2} \mathrm{CO}_{3}$ will change correspondingly. Spivey et al. directly ascribed FTIR bands at $1509 \mathrm{~cm}^{-1}$ and $1367 \mathrm{~cm}^{-1}$ to II- $\mathrm{La}_{2} \mathrm{O}_{2} \mathrm{CO}_{3}$ and Ia$\mathrm{La}_{2} \mathrm{O}_{2} \mathrm{CO}_{3}$, respectively. ${ }^{16}$ They concluded that only II- $\mathrm{La}_{2} \mathrm{O}_{2} \mathrm{CO}_{3}$ acts as a reactive species to eliminate coke while $\mathrm{Ia}-\mathrm{La}_{2} \mathrm{O}_{2} \mathrm{CO}_{3}$ merely acts as a spectator species. ${ }^{16}$ However, Kawi et al. reported that Ia- $\mathrm{La}_{2} \mathrm{O}_{2} \mathrm{CO}_{3}$ mainly participated in coke elimination rather than $\mathrm{II}-\mathrm{La}_{2} \mathrm{O}_{2} \mathrm{CO}_{3} \cdot{ }^{61}$ Combined with results of XRD patterns, Raman spectra and in situ DRIFTS spectra, we could conclude that bidentate carbonate is active for coke elimination and closely related to the II- $\mathrm{La}_{2} \mathrm{O}_{2} \mathrm{CO}_{3}$ phase while monodentate carbonate is inactive for coke elimination and closely related to the Ia- $\mathrm{La}_{2} \mathrm{O}_{2} \mathrm{CO}_{3}$ phase.

\section{Catalytic performance of coke elimination}

$\mathrm{H}_{2}$-TPR was carried out to investigate the decomposition behavior of $\mathrm{La}_{2} \mathrm{O}_{2} \mathrm{CO}_{3}$ formed on the series of Ce-La binary oxide under $\mathrm{a}_{2}$ atmosphere. The $\mathrm{H}_{2}$-TPR profiles are shown in Fig. 7. It should be mentioned that the formation of a reduction peak in $\mathrm{H}_{2}$-TPR profiles is due to the reaction of $\mathrm{H}_{2}$ and $\mathrm{CO}_{2}$ released during the decomposition of $\mathrm{La}_{2} \mathrm{O}_{2} \mathrm{CO}_{3}$. Herein, peaks at $450-500{ }^{\circ} \mathrm{C}$ correspond to the desorption of chemisorbed $\mathrm{CO}_{2} \cdot{ }^{9}$ With the increase of $\mathrm{Ce} / \mathrm{La}$ ratios, the desorption temperature of chemisorbed $\mathrm{CO}_{2}$ increases to higher temperature. It indicates that $\mathrm{Ce}$ addition can strengthen the chemisorption of $\mathrm{CO}_{2}$ on the surface of lanthanum species, while peaks at around $700{ }^{\circ} \mathrm{C}$ correspond to the decomposition of II$\mathrm{La}_{2} \mathrm{O}_{2} \mathrm{CO}_{3},{ }^{62}$ since the phase transformation of Ia- $\mathrm{La}_{2} \mathrm{O}_{2} \mathrm{CO}_{3}$ to 


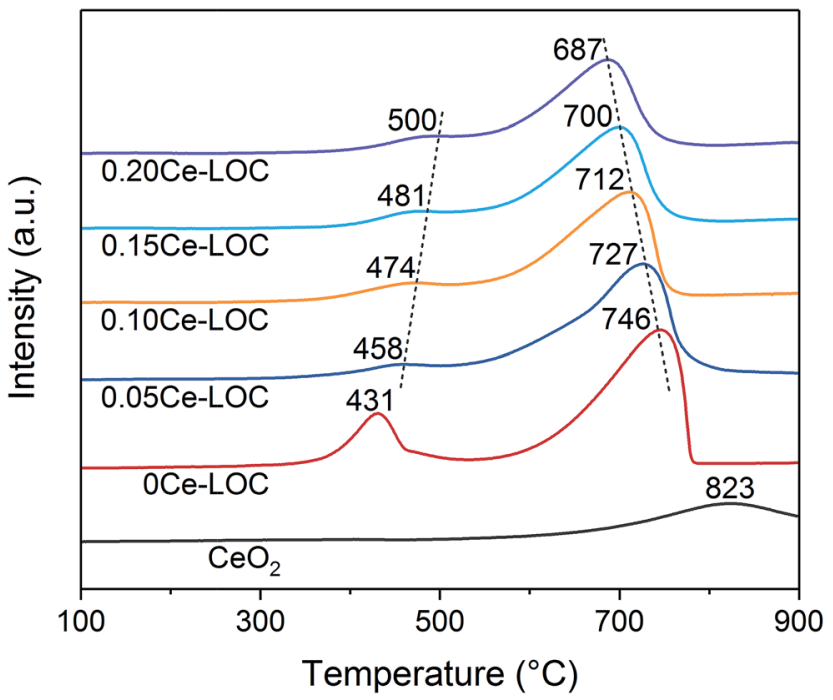

Fig. $7 \mathrm{H}_{2}$-TPR profiles of the series of $\mathrm{Ce}-\mathrm{La}$ binary oxides.

II- $-\mathrm{La}_{2} \mathrm{O}_{2} \mathrm{CO}_{3}$ is complete at around $600{ }^{\circ} \mathrm{C} .{ }^{12}$ With the increase of $\mathrm{Ce} / \mathrm{La}$ ratios, the decomposition temperature of II- $\mathrm{La}_{2} \mathrm{O}_{2} \mathrm{CO}_{3}$ under the $\mathrm{H}_{2}$ atmosphere decreases to a lower temperature, indicating that $\mathrm{Ce}$ addition can promote the decomposition of II- $\mathrm{La}_{2} \mathrm{O}_{2} \mathrm{CO}_{3}$ under the $\mathrm{H}_{2}$ atmosphere, which is related to the activity in the reaction of II- $\mathrm{La}_{2} \mathrm{O}_{2} \mathrm{CO}_{3}$ and coke.

In order to examine the performance of coke elimination, DRM reaction is used as a probe reaction, and then Ni particles are supported on the series of Ce-La binary oxide to produce coke. Ni loadings are fixed at $5 \mathrm{wt} \%$ for the series of Ce-La binary oxide to ensure that all catalysts exhibit similar $\mathrm{CH}_{4}$ conversions under appropriate reaction conditions.

$\mathrm{CO}_{2}$-TPD was employed to investigate the basicity of the $\mathrm{Ni}$ supported samples (Fig. 8). It has been extensively reported that the basicity of the support is beneficial to coke elimination. ${ }^{63}$

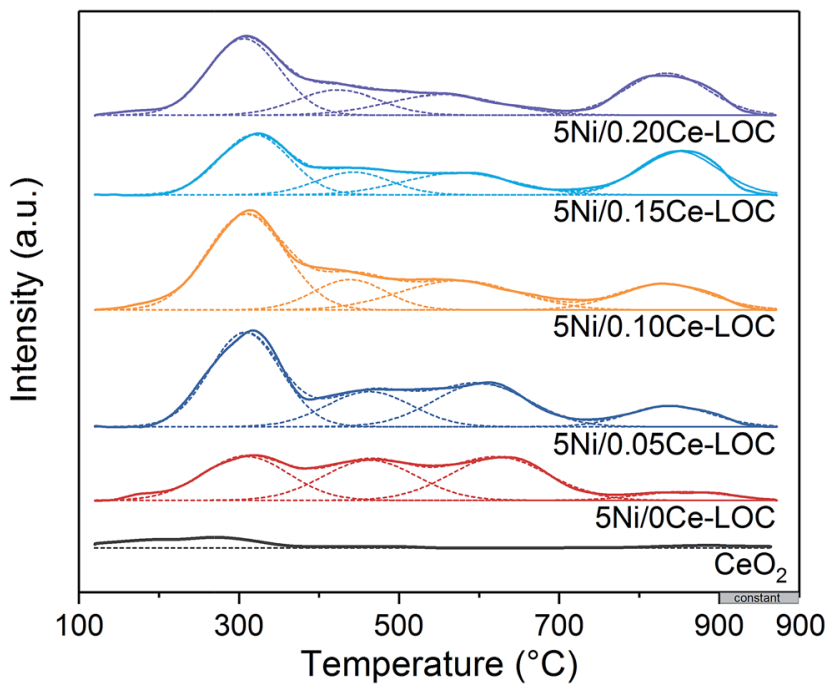

Fig. $8 \mathrm{CO}_{2}$-TPD profiles of the series of $\mathrm{Ni}$ supported $\mathrm{Ce}-\mathrm{La}$ binary oxides.
$\mathrm{CO}_{2}$ desorption will take place when the reaction temperature $\left(600-650^{\circ} \mathrm{C}\right)$ is higher than the desorption temperature. Thus, basicity with higher desorption temperature should be investigated. $\mathrm{CO}_{2}$-TPD profiles show that areas of peaks higher than $700{ }^{\circ} \mathrm{C}$ increase with the increment of $\mathrm{Ce} / \mathrm{La}$ ratio, and reach the maximum when the Ce/La ratio is 0.15 , and then decrease slightly when the Ce/La ratio is 0.20 . For pure $\mathrm{CeO}_{2}$ as a reference, the area of the peak higher than $700{ }^{\circ} \mathrm{C}$ is negligible, which indicates that pure $\mathrm{CeO}_{2}$ itself has much weaker $\mathrm{CO}_{2}$ adsorption compared with Ce-La binary oxide. According to the DRIFTS spectra (Fig. 4, 5 and S3 in the ESI $\dagger$ ), for the 0.15CeLOC sample, it has the highest intensity of bidentate carbonate during the $\mathrm{CH}_{4}$ adsorption. A previous study by Valange et al. has shown that bidentate carbonate has higher stability and hence higher basicity compared with monodentate carbonate. ${ }^{64}$ In addition, it has been reported that the decomposition temperature of $\mathrm{II}-\mathrm{La}_{2} \mathrm{O}_{2} \mathrm{CO}_{3}$ is higher than $700{ }^{\circ} \mathrm{C} .{ }^{13}$ Therefore, the desorption peaks higher than $700{ }^{\circ} \mathrm{C}$ can be ascribed to the decomposition of II- $\mathrm{La}_{2} \mathrm{O}_{2} \mathrm{CO}_{3}$. It should be mentioned that the atmosphere could affect the decomposition of $\mathrm{La}_{2} \mathrm{O}_{2} \mathrm{CO}_{3},{ }^{13}$ hence there is a difference in the decomposition temperature of II- $\mathrm{La}_{2} \mathrm{O}_{2} \mathrm{CO}_{3}$ between $\mathrm{CO}_{2}$-TPD and $\mathrm{H}_{2}$-TPR (Fig. 7 and 8). For the $0.15 \mathrm{Ce}-\mathrm{LOC}$ sample, it has the highest amount of bidentate carbonate after $\mathrm{CO}_{2}$ adsorption and the highest basicity above $700{ }^{\circ} \mathrm{C}$. It indicates that bidentate carbonate has a close relationship with II- $\mathrm{La}_{2} \mathrm{O}_{2} \mathrm{CO}_{3}$. Based on these facts, it is assumed that $\mathrm{Ce}$ addition can promote the transformation from monodentate carbonate to bidentate carbonate on $\mathrm{La}_{2} \mathrm{O}_{3}$ after $\mathrm{CO}_{2}$ adsorption, which will promote the formation of II- $\mathrm{La}_{2} \mathrm{O}_{2} \mathrm{CO}_{3}$. On the other hand, $\mathrm{H}_{2}$-TPR (Fig. 7) profiles show that Ce addition improves the activity of $\mathrm{II}-\mathrm{La}_{2} \mathrm{O}_{2} \mathrm{CO}_{3}$ under the $\mathrm{H}_{2}$ atmosphere.

DRM activity tests are applied to test the coke elimination performance of Ce-La binary oxide. GHSV has been adjusted to $60000 \mathrm{~mL} \mathrm{~h}^{-1} \mathrm{~g}_{\text {cat }}{ }^{-1}$ to ensure that different catalysts exhibit similar $\mathrm{CH}_{4}$ conversions. Spivey et al. reported that when the DRM reaction temperature is $550-650{ }^{\circ} \mathrm{C}$, the variation

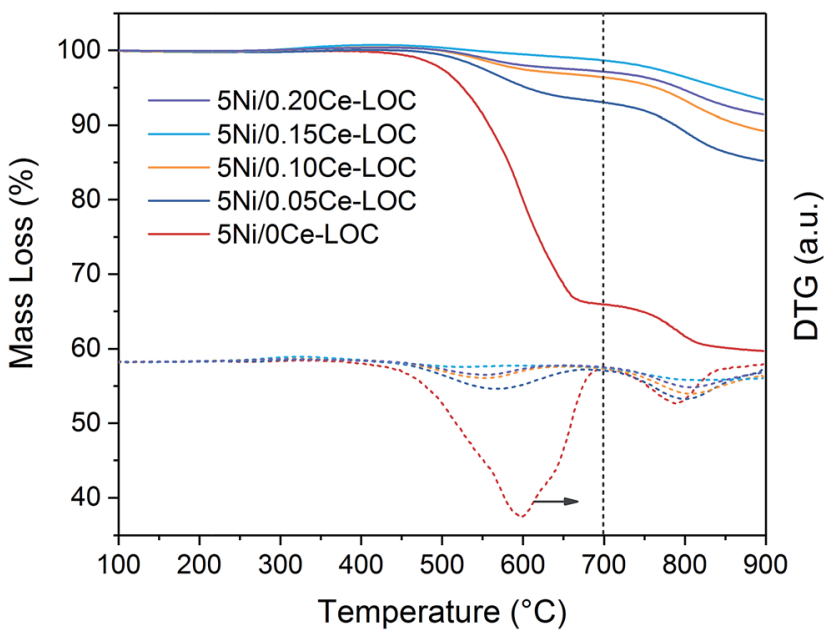

Fig. 9 TGA and DTG profiles for the spent catalysts (GHSV = $60000 \mathrm{~mL} \mathrm{~h}{ }^{-1} \mathrm{~g}_{\mathrm{cat}}{ }^{-1}, 650{ }^{\circ} \mathrm{C}$, time on stream: $50 \mathrm{~h}$ ). 
tendency of coke formation is much more severe since coke originates from both $\mathrm{CH}_{4}$ decomposition and Boudouard reaction. ${ }^{65}$ Therefore, the reaction temperature is fixed to $650{ }^{\circ} \mathrm{C}$ to increase the coke formation. As shown in Fig. S5 in the ESI, $\uparrow$ all the Ni catalysts have $\mathrm{CH}_{4}$ conversions at around $44 \%$ and exhibit good stability.

TGA profiles are shown in Fig. 9. The mass loss below $700{ }^{\circ} \mathrm{C}$ is ascribed to the oxidation of coke and Ni particles. And the mass loss above $700{ }^{\circ} \mathrm{C}$ is ascribed to the decomposition of $\mathrm{La}_{2} \mathrm{O}_{2} \mathrm{CO}_{3}$ to release $\mathrm{CO}_{2}$. At the end of TGA, all samples can be regarded as mixtures of $\mathrm{NiO}, \mathrm{La}_{2} \mathrm{O}_{3}$ and $\mathrm{CeO}_{2}$. According to the Ni loading, specific Ce/La ratio and mass loss obtained by TGA, the content of $\mathrm{Ni}, \mathrm{CeO}_{2}, \mathrm{La}_{2} \mathrm{O}_{2} \mathrm{CO}_{3}$ and $\mathrm{La}_{2} \mathrm{O}_{3}$ in the spent catalysts can be estimated (Table 2). It should be mentioned that the formation of $\mathrm{La}_{2} \mathrm{O}_{3}$ on the spent catalysts is due to the spontaneous reaction between II- $\mathrm{La}_{2} \mathrm{O}_{2} \mathrm{CO}_{3}$ and deposited coke. Additionally, since Ia$\mathrm{La}_{2} \mathrm{O}_{2} \mathrm{CO}_{3}$ is inactive for coke elimination and spontaneously transforms to $\mathrm{II}-\mathrm{La}_{2} \mathrm{O}_{2} \mathrm{CO}_{3}$ when the temperature is above $600{ }^{\circ} \mathrm{C},{ }^{12,16}$ the calculated content of $\mathrm{La}_{2} \mathrm{O}_{2} \mathrm{CO}_{3}$ (Table 2) is ascribed to the content of Ia- $\mathrm{La}_{2} \mathrm{O}_{2} \mathrm{CO}_{3}$ which transforms to II$\mathrm{La}_{2} \mathrm{O}_{2} \mathrm{CO}_{3}$ during the programmed temperature process. Therefore, we can use the calculated content of $\mathrm{La}_{2} \mathrm{O}_{3}$ and $\mathrm{La}_{2} \mathrm{O}_{2} \mathrm{CO}_{3}$ in Table 2 to estimate the content of II- $\mathrm{La}_{2} \mathrm{O}_{2} \mathrm{CO}_{3}$ and $\mathrm{Ia}-\mathrm{La}_{2} \mathrm{O}_{2} \mathrm{CO}_{3}$, respectively. Based on the results of DRIFTS (Fig. 4, 5 and $\mathrm{S} 3$ in the $\mathrm{ESI}^{\dagger}$ ), bidentate carbonate is active for coke elimination while monodentate carbonate is inactive for coke elimination. When correlating the molar ratio of $\mathrm{La}_{2} \mathrm{O}_{3} / \mathrm{La}_{2} \mathrm{O}_{2} \mathrm{CO}_{3}$ in Table 2 with the maximum intensity ratio of bidentate/monodentate carbonate peaks in Fig. 5, a linear relationship is obtained as shown in Fig. 10, which indicates that bidentate carbonate has a close relationship with $\mathrm{II}-\mathrm{La}_{2} \mathrm{O}_{2} \mathrm{CO}_{3}$ while monodentate carbonate is closely related to $\mathrm{Ia}-\mathrm{La}_{2} \mathrm{O}_{2} \mathrm{CO}_{3}$.

In addition, it can be found that the amount of coke decreases with the increase of $\mathrm{Ce} / \mathrm{La}$ ratio. For $5 \mathrm{Ni} / 0.15 \mathrm{Ce}-\mathrm{LOC}$, it has the lowest amount of coke and the highest molar ratio of $\mathrm{La}_{2} \mathrm{O}_{3} / \mathrm{La}_{2} \mathrm{O}_{2} \mathrm{CO}_{3}$ after $50 \mathrm{~h}$ DRM reaction, indicating that appropriate $\mathrm{Ce}$ addition can promote the formation of II$\mathrm{La}_{2} \mathrm{O}_{2} \mathrm{CO}_{3}$ to react with the deposited coke. According to the DTG profiles in Fig. 9, the peak temperature of filamentous coke $\left(\sim 550{ }^{\circ} \mathrm{C}\right)$ decreases with the increase of $\mathrm{Ce} / \mathrm{La}$ ratio which reflects the decrease of the graphitic degree of coke, ${ }^{4}$ while the peak temperature of II- $\mathrm{La}_{2} \mathrm{O}_{2} \mathrm{CO}_{3}\left(>700^{\circ} \mathrm{C}\right)$ exhibits the opposite variation tendency. Based on the above facts, it is concluded that the $0.15 \mathrm{Ce}-\mathrm{LOC}$ sample shows the best performance for coke elimination.

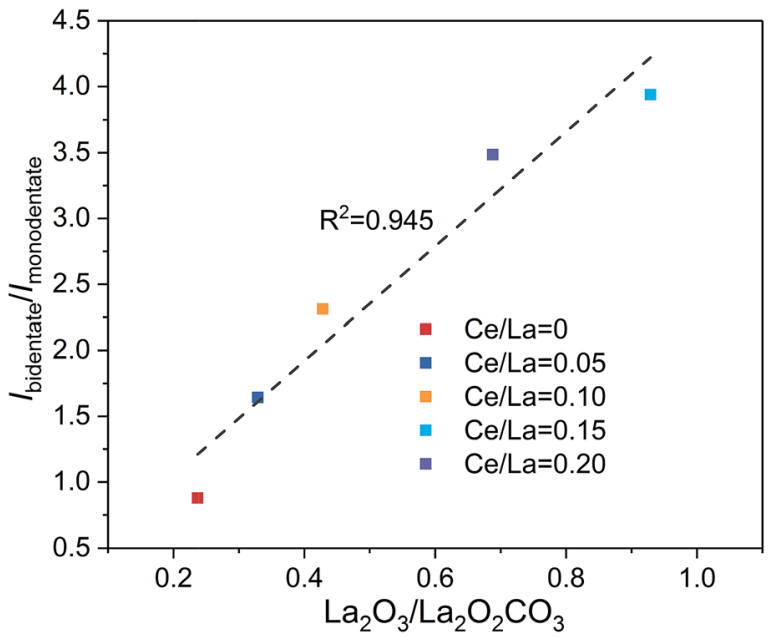

Fig. 10 Linear correlation between the molar ratio of $\mathrm{La}_{2} \mathrm{O}_{3} /$ $\mathrm{La}_{2} \mathrm{O}_{2} \mathrm{CO}_{3}$ obtained by TGA profiles and intensity ratio of bidentate/ monodentate carbonate obtained by DRIFTS.

\section{DFT calculation of $\mathrm{CO}_{2}$ adsorption energy}

DFT calculation was applied to illustrate the influence of Ce addition on the most stable $\mathrm{CO}_{2}$ adsorption mode on $\mathrm{La}_{2} \mathrm{O}_{2} \mathrm{CO}_{3}$ (Fig. 11). Ideally, models presuming that Ce atoms distribute along the surface layer were taken into consideration. In this case, a new $\mathrm{C}-\mathrm{O}$ bond is formed between a $\mathrm{CO}_{2}$ molecule with a surface $\mathrm{O}$ atom on $\mathrm{La}_{2} \mathrm{O}_{2} \mathrm{CO}_{3}$, which leads to the formation of carbonate. The calculated frequency of the formed $\mathrm{C}-\mathrm{O}$ bond is $1517 \mathrm{~cm}^{-1}$, which is close to the characteristic frequency of bidentate carbonate $\left(1560 \mathrm{~cm}^{-1}\right)$ collected by in situ DRITFS (Fig. 4). In addition, the calculated $\mathrm{CO}_{2}$ adsorption energy for pure II- $\mathrm{La}_{2} \mathrm{O}_{2} \mathrm{CO}_{3}\left((\mathrm{Ce} / \mathrm{La})_{\mathrm{s}}\right.$ is equal to 0 , the subscript $\mathrm{s}$ denotes surface) is $-1.39 \mathrm{eV}$, which is a negative value since it is an exothermic adsorption process.

When the ratio of $(\mathrm{Ce} / \mathrm{La})_{\mathrm{s}}$ is equal to $1: 7$, there are eight possible sites for a Ce atom to replace a La atom within our selected unit cell (Fig. S6 in the ESI $\dagger$ ). DFT calculations predict that the most stable $\mathrm{CO}_{2}$ adsorption mode takes place when the La atom at site 4 (see the definition in Fig. 11) is replaced by a Ce atom and the calculated $\mathrm{CO}_{2}$ adsorption energy is $-1.50 \mathrm{eV}$. For samples with higher Ce content, the selected model was based on the most stable structure of samples with lower Ce contents. For example, when the ratio of $(\mathrm{Ce} / \mathrm{La})_{\mathrm{s}}$ is equal to $1: 3$, one Ce atom is fixed at the fourth site on the basis of the obtained

Table 2 Quantitative analysis of TGA profiles

\begin{tabular}{|c|c|c|c|c|c|c|c|c|c|c|}
\hline \multirow[b]{2}{*}{ Sample } & \multicolumn{2}{|c|}{ Mass loss (\%) } & \multicolumn{5}{|c|}{ Component in the spent catalysts (\%) } & \multirow{2}{*}{$\begin{array}{l}\text { Molar ratio of } \\
\mathrm{La}_{2} \mathrm{O}_{3} / \mathrm{La}_{2} \mathrm{O}_{2} \mathrm{CO}_{3}\end{array}$} & \multirow{2}{*}{$\begin{array}{l}\text { Amount of } \\
\text { coke }\left(g g_{\text {cat }}{ }^{-1}\right)\end{array}$} & \multirow{2}{*}{$\begin{array}{l}\text { Rate of coke formation } \\
\left(\mu \mathrm{mol} \mathrm{g}_{\text {cat }}^{-1} \cdot \mathrm{s}^{-1}\right)\end{array}$} \\
\hline & $<700{ }^{\circ} \mathrm{C}$ & $>700{ }^{\circ} \mathrm{C}$ & Coke & $\mathrm{Ni}$ & $\mathrm{CeO}_{2}$ & $\mathrm{La}_{2} \mathrm{O}_{2} \mathrm{CO}_{3}$ & $\mathrm{La}_{2} \mathrm{O}_{3}$ & & & \\
\hline $5 \mathrm{Ni} / 0 \mathrm{Ce}-\mathrm{LOC}$ & 33.9 & 6.2 & 33.9 & 3.1 & 0 & 52.1 & 10.9 & 0.237 & 0.513 & 0.237 \\
\hline $5 \mathrm{Ni} / 0.05 \mathrm{Ce}-\mathrm{LOC}$ & 6.9 & 7.8 & 6.9 & 4.4 & 4.2 & 65.5 & 19.0 & 0.329 & 0.074 & 0.034 \\
\hline $5 \mathrm{Ni} / 0.10 \mathrm{Ce}-\mathrm{LOC}$ & 3.9 & 7.2 & 3.9 & 4.5 & 8.2 & 60.5 & 22.8 & 0.428 & 0.041 & 0.019 \\
\hline $5 \mathrm{Ni} / 0.15 \mathrm{Ce}-\mathrm{LOC}$ & 2.2 & 5.3 & 2.2 & 4.7 & 12.1 & 44.5 & 36.5 & 0.929 & 0.022 & 0.010 \\
\hline $5 \mathrm{Ni} / 0.20 \mathrm{Ce}-\mathrm{LOC}$ & 3.2 & 5.7 & 3.2 & 4.6 & 15.3 & 47.9 & 29.0 & 0.688 & 0.033 & 0.015 \\
\hline
\end{tabular}




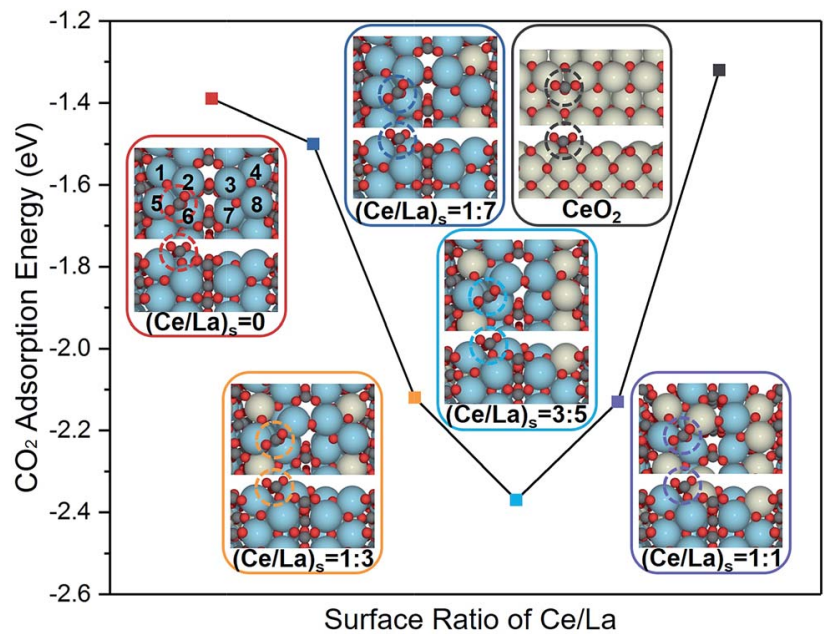

Fig. 11 Calculated $\mathrm{CO}_{2}$ adsorption energies on the surfaces of $\mathrm{Ce}-\mathrm{La}$ binary oxides and corresponding top and side views of geometries with $\mathrm{CO}_{2}$ adsorbed on the top site of binary oxides. Colors: yellow, $\mathrm{Ce}$; blue, La; grey, $\mathrm{C}$; and red, $\mathrm{O}$.

calculation (Fig. S7 in the ESI $\dagger$ ). In this case, the most stable $\mathrm{CO}_{2}$ adsorption mode takes place when La atoms located at sites 1 and 4 are replaced by Ce atoms and the calculated adsorption energy is $-2.12 \mathrm{eV}$. Following the same procedure, when the ratio of $(\mathrm{Ce} / \mathrm{La})_{\mathrm{s}}$ increases to $3: 5$ and $1: 1$, the strongest adsorption energy of $\mathrm{CO}_{2}$ over Ce-La binary oxides is $-2.37 \mathrm{eV}$ (Fig. S8 in the ESI $\dagger$ ) and $-2.13 \mathrm{eV}$ (Fig. S9 in the ESI $\dagger$ ), respectively. Meanwhile, twenty extra models with randomly distributed Ce structures were tested, which did not follow the mentioned procedure. The $\mathrm{CO}_{2}$ binding over all these randomly generated models is less stable than the ones discussed above (Table $\mathrm{S} 1$ in the ESI $\dagger$ ). Additionally, the calculated $\mathrm{CO}_{2}$ adsorption energy for pure $\mathrm{CeO}_{2}$ is $-1.32 \mathrm{eV}$, which is weaker than that of $\mathrm{La}_{2} \mathrm{O}_{2} \mathrm{CO}_{3}$ and other Ce-La binary oxides. It indicates that the intensity of $\mathrm{CO}_{2}$ adsorption on ceria is much weaker than that of $\mathrm{La}_{2} \mathrm{O}_{2} \mathrm{CO}_{3}$ and other Ce-La binary oxides, which is responsible for the absence of bidentate carbonate on $\mathrm{CeO}_{2}$ as shown in Fig. 4.

According to the results of DFT calculation (Fig. 11), with the increase of $(\mathrm{Ce} / \mathrm{La})_{\mathrm{s}}$ ratios, the $\mathrm{CO}_{2}$ adsorption energy gradually becomes lower and reaches the lowest value when $(\mathrm{Ce} / \mathrm{La})_{\mathrm{s}}$ is equal to $3: 5$, and then the $\mathrm{CO}_{2}$ adsorption energy weakens. The variation tendency of $\mathrm{CO}_{2}$ adsorption energy with the increase of $(\mathrm{Ce} / \mathrm{La})_{\mathrm{s}}$ ratios (Fig. 11) is consistent with the variation tendency for the peak intensity of bidentate carbonate on Ce-La binary oxides (Fig. 4). As the $\mathrm{CO}_{2}$ adsorption energy becomes lower, $\mathrm{CO}_{2}$ adsorption on binary oxide is strengthened, and the formed carbonate is expected to have better stability. Therefore, Ce addition can affect $\mathrm{CO}_{2}$ adsorption energy for Ce-La binary oxide and the type of carbonate formed after $\mathrm{CO}_{2}$ adsorption. Ce-La binary oxide with the optimal $\mathrm{Ce} / \mathrm{La}$ ratio exhibits the highest intensity of bidentate carbonate (Fig. 4), and hence has the highest basicity above $700{ }^{\circ} \mathrm{C}$ (Fig. 8) and shows the best coke elimination performance (Fig. 9).

\section{Conclusion}

We have investigated the role of Ce addition in $\mathrm{CO}_{2}$ adsorption and activation over lanthanum species. Based on results of in situ DRIFTS spectra, DFT calculations and other experimental characterizations, it is concluded that Ce addition can promote the formation of bidentate carbonate on Ce-La binary oxide via tuning $\mathrm{CO}_{2}$ adsorption energy. With the increase of Ce/La ratio from 0 to 0.20 , Ce addition facilitates transformation from monodentate carbonate to bidentate carbonate on Ce-La binary oxides. Bidentate carbonate is verified to be active in the reaction with deposited coke, while monodentate carbonate is inactive for coke elimination. With the consumption of bidentate carbonate, the variation of the intensity ratio of bidentate/ monodentate carbonate can affect the ratio of II- $\mathrm{La}_{2} \mathrm{O}_{2} \mathrm{CO}_{3} / \mathrm{Ia}$ $\mathrm{La}_{2} \mathrm{O}_{2} \mathrm{CO}_{3}$. Bidentate carbonate is verified to be closely related to II- $\mathrm{La}_{2} \mathrm{O}_{2} \mathrm{CO}_{3}$ and monodentate carbonate has a close relationship with $\mathrm{Ia}_{-} \mathrm{La}_{2} \mathrm{O}_{2} \mathrm{CO}_{3}$. When the $\mathrm{Ce} / \mathrm{La}$ ratio is 0.15 , the corresponding nickel catalyst has the highest intensity ratio of bidentate/monodentate carbonate and the highest ratio of II$\mathrm{La}_{2} \mathrm{O}_{2} \mathrm{CO}_{3} / \mathrm{Ia}_{-} \mathrm{La}_{2} \mathrm{O}_{2} \mathrm{CO}_{3}$, which exhibits the highest basicity above $700{ }^{\circ} \mathrm{C}$ and the best performance of coke elimination after $50 \mathrm{~h}$ DRM reaction.

\section{Experimental section}

\section{Catalyst preparation}

Analytical grade $\mathrm{La}\left(\mathrm{NO}_{3}\right)_{3} \cdot 6 \mathrm{H}_{2} \mathrm{O}, \mathrm{Ce}\left(\mathrm{NO}_{3}\right)_{3} \cdot 6 \mathrm{H}_{2} \mathrm{O}, \mathrm{Ni}\left(\mathrm{NO}_{3}\right)_{2}$ $\cdot 6 \mathrm{H}_{2} \mathrm{O}$ and $\mathrm{CeO}_{2}$ powder were obtained from Aladdin Industrial Corporation (Shanghai, China). Analytical grade aqueous ammonia (25 wt\%) and anhydrous ethanol (99.8 wt\%) were obtained from Guangfu Fine Chemical Research Institute (Tianjin, China). Guaranteed grade urea was supplied by Kermel Chemical Reagent (Tianjin, China). De-ionized water (18.0 $\mathrm{M} \Omega$ ) was prepared using an Ulupure water purifier machine (Chengdu, China).

The synthesis route of $\mathrm{La}_{2} \mathrm{O}_{2} \mathrm{CO}_{3}$ is described as follows. 2.6 grams of $\mathrm{La}\left(\mathrm{NO}_{3}\right)_{3} \cdot 6 \mathrm{H}_{2} \mathrm{O}$ and 7.2 grams of urea were separately dissolved in de-ionized water. Once dissolved, the two solutions were mixed with constant stirring; the concentrations of $\mathrm{La}^{3+}$ and urea in the mixture were $0.015 \mathrm{~mol} \mathrm{~L}^{-1}$ and $0.30 \mathrm{~mol} \mathrm{~L}^{-1}$, respectively. Then aqueous ammonia was added into the mixture to adjust the $\mathrm{pH}$ to 8.5. A white suspension was obtained after heating in a water bath at $90{ }^{\circ} \mathrm{C}$ for $3 \mathrm{~h}$ with constant stirring, followed by naturally cooling to room temperature. Afterwards, the white suspension was centrifuged and washed with absolute ethanol three times. $\mathrm{La}_{2} \mathrm{O}_{2} \mathrm{CO}_{3}$ was finally prepared upon drying at $80{ }^{\circ} \mathrm{C}$ overnight and calcination at $500{ }^{\circ} \mathrm{C}$ for $2 \mathrm{~h}$.

A series of Ce-La binary oxides were prepared by a wet impregnation method. The stoichiometric $\mathrm{Ce} / \mathrm{La}$ ratio was chosen as $0,0.05,0.10,0.15$, and 0.20 , respectively. The prepared $\mathrm{La}_{2} \mathrm{O}_{2} \mathrm{CO}_{3}$ was impregnated with an aqueous solution containing a specified amount of $\mathrm{Ce}\left(\mathrm{NO}_{3}\right)_{2} \cdot 6 \mathrm{H}_{2} \mathrm{O}$. Upon stirring at $80{ }^{\circ} \mathrm{C}$ for $3 \mathrm{~h}$, vacuum evaporation was carried out to remove the solvent. Then the sample was dried overnight, and ground and calcined at $600{ }^{\circ} \mathrm{C}$ for $2 \mathrm{~h}$. The prepared Ce-La binary oxide 
was marked as " $x$ Ce-LOC", where LOC denotes the prepared $\mathrm{La}_{2} \mathrm{O}_{2} \mathrm{CO}_{3}$ and $x$ denotes the specific stoichiometric Ce/La ratio.

A series of Ni catalysts supported on the prepared Ce-La binary oxide were synthesized by a similar procedure to that described above. For the subsequent wet impregnation method the Ni loading was fixed at $5 \mathrm{wt} \%$ on the basis of reduction conditions. When the sample was impregnated with the $\mathrm{Ni}$ precursor and dried overnight, it was ground and calcined at $650{ }^{\circ} \mathrm{C}$ for $2 \mathrm{~h}$. After grinding to 20-40 mesh, the sample was reduced at $650{ }^{\circ} \mathrm{C}$ under a $\mathrm{H}_{2}$ atmosphere $\left(\mathrm{H}_{2} / \mathrm{N}_{2}=1: 3,40\right.$ $\mathrm{mL} \min ^{-1}$ ) for $60 \mathrm{~min}$. The prepared catalyst was named $5 \mathrm{Ni}$ / $x \mathrm{Ce}$-LOC, where LOC denotes the prepared $\mathrm{La}_{2} \mathrm{O}_{2} \mathrm{CO}_{3}$ and $x$ denotes the specific Ce/La ratio.

\section{Characterization}

Textural properties of catalysts were measured through nitrogen adsorption-desorption at $-196{ }^{\circ} \mathrm{C}$ using a Micromeritics Tristar 3000 analyzer. All samples were degassed at $300{ }^{\circ} \mathrm{C}$ for $3 \mathrm{~h}$ prior to the tests. The specific surface areas were calculated on the basis of the $\mathrm{N}_{2}$ isotherms and the Brunauer-Emmett-Teller (BET) method. Combined with the Barrett-Joyner-Halenda (BJH) method and the desorption branches of the $\mathrm{N}_{2}$ isotherms, cumulative volumes of pores were obtained.

Elemental contents of the prepared catalysts were examined by inductively coupled plasma optical emission spectroscopy (ICP-OES) (VISTA-MPX, Varian) at a high frequency emission power of $1.5 \mathrm{~kW}$ and a plasma airflow of $15.0 \mathrm{~L} \mathrm{~min} \min ^{-1}\left(\lambda_{\mathrm{Ni}}=\right.$ $\left.231.60 \mathrm{~nm}, \lambda_{\mathrm{La}}=379.48 \mathrm{~nm}, \lambda_{\mathrm{Ce}}=413.76 \mathrm{~nm}\right)$. Prior to measurements, samples were dissolved in a mixture of nitric acid and $\mathrm{H}_{2} \mathrm{O}_{2}$ to ensure that the concentrations of the measured elements are close to the concentrations of the prepared standard solutions.

XRD patterns were examined through a Rigaku D/max-2500 diffractometer equipped with graphite filtered $\mathrm{Cu} K \alpha$ radiation $(\lambda=1.54056 \AA)$, and $2 \theta$ values range from $20^{\circ}$ to $80^{\circ}$. The mean crystalline size of Ni particles was calculated by Scherrer's equation according to the diffraction peaks of $\mathrm{Ni}$ (111) facets.

$\mathrm{H}_{2}$-TPR experiment was applied to analyze the reduction behavior of the catalysts with the aid of a chemisorption apparatus (Micromeritics AutoChem II 2920). $100 \mathrm{mg}$ of the sample was pretreated at $300{ }^{\circ} \mathrm{C}$ for $1 \mathrm{~h}$ with an Ar stream (30 $\mathrm{mL} \mathrm{min}^{-1}$ ) to remove moisture and impurities. After cooling to $50{ }^{\circ} \mathrm{C}$, the system was exposed to a $10 \mathrm{vol} \% \mathrm{H}_{2} / \mathrm{Ar}$ stream $(30$ $\mathrm{mL} \min ^{-1}$ ) to reduce the sample. Subsequently, the temperature of the system was programmed to rise linearly from $100{ }^{\circ} \mathrm{C}$ to $900{ }^{\circ} \mathrm{C}$ with a rate of $10{ }^{\circ} \mathrm{C} \mathrm{min}^{-1}$, during which variation of the signal of the thermal conductivity detector (TCD) was recorded.

$\mathrm{CO}_{2}$-TPD analysis was applied to investigate the basicity of the catalyst by utilizing the same chemisorption apparatus (Micromeritics AutoChem II 2920). $100 \mathrm{mg}$ of the sample was prereduced at $750{ }^{\circ} \mathrm{C}$ with a 10 vol\% $\mathrm{H}_{2} / \mathrm{Ar}$ stream (50 $\mathrm{mL} \min ^{-1}$ ) for $30 \mathrm{~min}$ to completely decompose existing $\mathrm{La}_{2} \mathrm{O}_{2} \mathrm{CO}_{3}$ on samples before $\mathrm{CO}_{2}$ adsorption. After cooling to $60{ }^{\circ} \mathrm{C}$, the system was exposed to a stream of $\mathrm{CO}_{2}$ gas (50 $\mathrm{mL} \min ^{-1}$ ) to carry out $\mathrm{CO}_{2}$ adsorption for $30 \mathrm{~min}$. Next, the system was exposed to a He stream $\left(30 \mathrm{~mL} \mathrm{~min}^{-1}\right)$ and the temperature was programmed to increase to $120{ }^{\circ} \mathrm{C}$ for the removal of residual $\mathrm{CO}_{2}$ in the stream. Once the signal of TCD reached a stable state, the temperature of the system was programmed to increase from $120{ }^{\circ} \mathrm{C}$ to $900{ }^{\circ} \mathrm{C}$ with a ramping rate of $10{ }^{\circ} \mathrm{C} \mathrm{min}^{-1}$ and at the same time the system starts to keep record of the TCD signal. An isothermal period lasting for 8 minutes at $900{ }^{\circ} \mathrm{C}$ was set to ensure that the adsorbed $\mathrm{CO}_{2}$ was totally desorbed.

A TEM instrument (FEI Tecnai G2 F20) was applied to investigate the morphology and structure of catalysts, and the working voltage was $100 \mathrm{kV}$. After the sample powder was dispersed in absolute ethanol via ultrasonication, the obtained suspension was dripped onto a copper grid-supported transparent carbon foil and dried in air for characterization.

XPS analysis of the catalysts was carried out on a PerkinElmer PHI 1600 ESCA system equipped with an Al KR X-ray source $(E=1486.6 \mathrm{eV})$. Spectra were operated at a pass energy of $187.85 \mathrm{eV}$. The binding energy (B.E.) scale was measured on the basis of carbon contamination utilizing $\mathrm{C}$ 1s peak centered at $285 \mathrm{eV}$. In addition, core peaks were obtained using a nonlinear Shirley-type background. Besides, quantification of surface elemental composition was carried out according to Scofield's relative sensitivity factors. ${ }^{66}$

Properties of the coke deposited on the spent catalysts were characterized by utilizing a TGA system (STA449F3, NETZSCH Corp.). The TGA experiment was conducted in an air stream (50 $\mathrm{mL} \mathrm{min}^{-1}$ ), and the temperature was programmed to rise from room temperature to $900{ }^{\circ} \mathrm{C}$ with a heating rate of $10{ }^{\circ} \mathrm{C} \mathrm{min}{ }^{-1}$. The amount of coke deposition, II- $\mathrm{La}_{2} \mathrm{O}_{2} \mathrm{CO}_{3}$ accumulation and oxidation of Ni particles were calculated according to the mass losses in TGA profiles.

A Raman spectrometer (Renishaw inVia Reex) was employed to record Raman spectra under ambient conditions, which was equipped with a $532 \mathrm{~nm}$ Ar-ion laser beam as the excitation source. Each sample was examined more than three times at different positions.

UV-visible reflectance spectra were collected on a SHIMADZU UV-2550 spectrophotometer using a pressed disc of the sample. Kubelka-Munk transformed diffuse reflectance spectra (DRS) of all samples were measured with $\mathrm{BaSO}_{4}$ powder as a reference.

\section{In situ DRIFTS measurements}

In situ DRIFTS experiments were performed on a ThermoFisher Nicolet IS50 spectrometer, which was equipped with a Harrick Scientific diffuse reflection accessory and a mercury-cadmiumtelluride (MCT) detector. The scheme of the experimental process is shown in Fig. 1. The Ce-La binary oxide samples were placed in the cell of the DRIFTS apparatus and reduced at $600{ }^{\circ} \mathrm{C}$ under 30 vol\% $\mathrm{H}_{2} / \mathrm{Ar}$ stream $\left(30 \mathrm{~mL} \mathrm{~min}^{-1}\right)$. And then, the gas stream was switched from $\mathrm{H}_{2} /$ Ar stream to Ar stream (30 $\mathrm{mL} \min ^{-1}$ ) in order to remove hydrogen in the gas stream. Subsequently, the baseline of DRIFTS was collected continuously until the obtained baseline spectra remained stable. Afterwards, the gas stream was switched to $10 \mathrm{vol} \% \mathrm{CO}_{2} / \mathrm{Ar}$ stream $\left(30 \mathrm{~mL} \mathrm{~min}{ }^{-1}\right)$ to carry out $\mathrm{CO}_{2}$ adsorption for $30 \mathrm{~min}$, 
after which the $\mathrm{CO}_{2}$ adsorption was saturated. The moment at the end of $\mathrm{CO}_{2}$ adsorption was marked as "0 min". Subsequently, the gas stream was switched from $10 \mathrm{vol} \% \mathrm{CO}_{2} / \mathrm{Ar}$ stream to $10 \mathrm{vol} \% \mathrm{CH}_{4} / \mathrm{Ar}$ stream $\left(30 \mathrm{~mL} \mathrm{~min}^{-1}\right)$ in order to carry out $\mathrm{CH}_{4}$ adsorption for $30 \mathrm{~min}$. The moment at the end of $\mathrm{CH}_{4}$ adsorption was marked as "30 min". In situ DRIFTS measurements were carried out from "0 min" to "30 min". Since DRIFTS spectra remained stable after "30 min", it could be regarded that the reaction took place completely. Additionally, when it is " 0 min" or " 30 min", subsequent operations could be skipped and the temperature would decrease from $600{ }^{\circ} \mathrm{C}$ to room temperature. When the cell was cooled to room temperature, samples could be taken out to carry out ex situ characterizations.

\section{Periodic DFT calculations}

Periodic DFT calculations were carried out with the assistance of Vienna $a b$ initio Simulation Package (VASP). ${ }^{67}$ The calculations employed the generalized-gradient approximation (GGA) in the form of the Perdew-Burke-Ernzerhof (PBE) exchangecorrelation functional. ${ }^{68}$ A Hubbard $U$ value was added to the PBE functional (DFT $+\mathrm{U}$ ), which is chosen to improve the quality of the DFT calculations in dealing with oxides having narrow $\mathrm{f}$ or $\mathrm{d}$ bands. ${ }^{69}$ The interactions between the atomic cores and electrons were described by the projector augmented wave (PAW) method. ${ }^{70}$ The valence wave functions were expanded using plane-wave with a cutoff energy of $400 \mathrm{eV}$. A $4 \times$ 2 cell was used for $\mathrm{La}_{2} \mathrm{O}_{2} \mathrm{CO}_{3}$ (110) and $\mathrm{CeO}_{2}$ (110) surfaces, and a $3 \times 1 \times 1 k$-point mesh was used for the Brillouin zone integration. The slab was three layers thick and separated by $15 \AA$ of vaccum. The top two layers of the slab were allowed to relax, while the bottom one layer was kept fixed. For La, a value of $U_{\text {eff }}$ $=7.5 \mathrm{eV}$ was used, which was calculated self-consistently by Metiu et al. ${ }^{19} U_{\text {eff }}=4.5 \mathrm{eV}$ was employed for Ce, which was reported by Fabris et al. $^{71}$

The adsorption energy of adsorbates, $E_{\text {ads }}$, is defined as follows:

$$
E_{\mathrm{ads}}=E_{\mathrm{total}}-E_{\mathrm{gas}}-E_{\mathrm{slab}}
$$

where $E_{\text {total }}$ is the total energy of the system after adsorption, $E_{\text {gas }}$ is the energy of the adsorbate in the gas phase, and $E_{\text {slab }}$ is the energy of the clean slab. Thus, a negative value means an exothermic adsorption process.

\section{Coke elimination performance test}

Catalytic activity tests were carried out in a quartz fixed-bed tubular reactor $(\Phi 8 \times 44 \mathrm{~mm})$ under atmospheric pressure. Prior to the test, the catalyst sample (100 mg, 20-40 mesh) was evenly mixed with $1 \mathrm{~mL}$ of quartz particles and then the mixture was loaded inside the reactor. Prior to the test, the catalysts were reduced at $650{ }^{\circ} \mathrm{C}$ under a $25 \mathrm{vol} \% \mathrm{H}_{2} / \mathrm{N}_{2}$ stream $\left(40 \mathrm{~mL} \mathrm{~min}^{-1}\right)$ for an hour. The flow rate of the feed gas was set at 100 $\mathrm{mL} \min ^{-1}$ (GHSV $=60000 \mathrm{~mL} \mathrm{~h}^{-1} \mathrm{~g}_{\text {cat }}{ }^{-1}, \mathrm{CH}_{4}: \mathrm{CO}_{2}: \mathrm{N}_{2}=$ $20: 20: 60 \mathrm{~mL} \mathrm{~min}^{-1}$ ) to ensure that the activities of the catalysts are close to each other to simplify the comparison of coke deposition. Here, the mentioned GHSV is based on a total flow. The concentrations of gas species including $\mathrm{CH}_{4}, \mathrm{CO}_{2}, \mathrm{H}_{2}, \mathrm{CO}$, and $\mathrm{N}_{2}$ were measured online with the assistance of a gas chromatograph (GC2060, Shanghai Ruimin Instrument). Helium was used as the carrier gas. The GC was equipped with a TCD and two columns including a TDX-01 column followed by a 5 A molecular sieve column. Activity test was performed at $650{ }^{\circ} \mathrm{C}$ for $50 \mathrm{~h}$. Conversions of $\mathrm{CH}_{4}$ and $\mathrm{CO}_{2}\left(X_{\mathrm{CH}_{4}}\right.$ and $\left.X_{\mathrm{CO}_{2}}\right)$, selectivities to $\mathrm{H}_{2}$ and $\mathrm{CO}\left(S_{\mathrm{H}_{2}}\right.$ and $\left.S_{\mathrm{CO}}\right)$, and the $\mathrm{H}_{2} / \mathrm{CO}$ ratio are defined as follows:

$$
\begin{gathered}
X_{\mathrm{CH}_{4}}=\frac{F_{\mathrm{CH}_{4}, \text { in }}-F_{\mathrm{CH}_{4}, \text { out }}}{F_{\mathrm{CH}_{4}, \text { in }}} \\
X_{\mathrm{CO}_{2}}=\frac{F_{\mathrm{CO}_{2}, \text { in }}-F_{\mathrm{CO}_{2}, \text { out }}}{F_{\mathrm{CO}_{2}, \text { in }}} \\
S_{\mathrm{CO}}=\frac{F_{\mathrm{H}_{2}, \text { out }}}{\left(F_{\mathrm{CH}_{4}, \text { in }}-F_{\mathrm{CH}_{4}, \text { out }}\right)+\left(F_{\mathrm{CO}_{2}, \text { in }}-F_{\mathrm{CO}_{2}, \text { out }}\right)} \\
\frac{\left.F_{\mathrm{CO}_{4}, \text { out }}-F_{\mathrm{CH}_{4}, \text { out }}\right)}{2 \times\left(F_{\mathrm{C}_{2}} / \mathrm{CO}=\frac{F_{\mathrm{H}_{2} \text { out }}}{F_{\mathrm{CO}, \text { out }}}\right.}
\end{gathered}
$$

\section{Conflicts of interest}

There are no conflicts to declare.

\section{Acknowledgements}

We thank the National Key R\&D Program of China (2016YFB0600901), the National Natural Science Foundation of China (No. 51761145012, 21525626, and U1663224) and the Program of Introducing Talents of Discipline to Universities (No. B06006) for financial support.

\section{References}

1 C. Montero, A. Ochoa, P. Castaño, J. Bilbao and A. G. Gayubo, J. Catal., 2015, 331, 181-192.

2 S. Singh, D. Zubenko and B. A. Rosen, ACS Catal., 2016, 6, 4199-4205.

3 H. Chen, H. Yu, F. Peng, H. Wang, J. Yang and M. Pan, J. Catal., 2010, 269, 281-290.

4 X. Li, D. Li, H. Tian, L. Zeng, Z.-J. Zhao and J. Gong, Appl. Catal., B, 2017, 202, 683-694.

5 X. E. Verykios, Int. J. Hydrogen Energy, 2003, 28, 1045-1063.

6 Z. Zhang, X. E. Verykios, S. M. MacDonald and S. Affrossman, J. Phys. Chem., 1996, 100, 744-754.

7 Z. Zhang and X. E. Verykios, Appl. Catal., A, 1996, 138, 109133.

8 V. A. Tsipouriari and X. E. Verykios, Catal. Today, 2001, 64, 83-90. 
9 Y. H. Hou, W. C. Han, W. S. Xia and H. L. Wan, ACS Catal., 2015, 5, 1663-1674.

10 R. P. Taylor and G. L. Schrader, Ind. Eng. Chem. Res., 1991, 30, 1016-1023.

11 R. P. Turcotte, J. O. Sawyer and L. Eyring, Inorg. Chem., 1969, 8, 238-246.

12 A. Orera, G. Larraz and M. L. Sanjuán, J. Eur. Ceram. Soc., 2013, 33, 2103-2110.

13 S. Irusta, L. M. Cornaglia and E. A. Lombardo, Mater. Chem. Phys., 2004, 86, 440-447.

14 T. Levan, M. Che, J. M. Tatibouet and M. Kermarec, J. Catal., 1993, 142, 18-26.

15 B. Klingenberg and M. A. Vannice, Chem. Mater., 1996, 8, 2755-2768.

16 D. Pakhare, V. Schwartz, V. Abdelsayed, D. Haynes, D. Shekhawat, J. Poston and J. Spivey, J. Catal., 2014, 316, 78-92.

17 G. Yang, H. Yu, X. Huang, F. Peng and H. Wang, Appl. Catal., B, 2012, 127, 89-98.

18 L. Jin, Y. Zhang, J. P. Dombrowski, C.-H. Chen, A. Pravatas, L. Xu, C. Perkins and S. L. Suib, Appl. Catal., B, 2011, 103, 200-205.

19 B. Li and H. Metiu, J. Phys. Chem. C, 2010, 114, 12234-12244. 20 B. Li and H. Metiu, J. Phys. Chem. C, 2011, 115, 18239-18246. 21 T. Montini, M. Melchionna, M. Monai and P. Fornasiero, Chem. Rev., 2016, 116, 5987-6041.

22 J. A. Rodriguez, D. C. Grinter, Z. Liu, R. M. Palomino and S. D. Senanayake, Chem. Soc. Rev., 2017, 46, 1824-1841.

23 S. Bhavsar, N. Isenberg, A. More and G. Veser, Appl. Energy, 2016, 168, 236-247.

24 W. Xu, Z. Liu, A. C. Johnston-Peck, S. D. Senanayake, G. Zhou, D. Stacchiola, E. A. Stach and J. A. Rodriguez, ACS Catal., 2013, 3, 975-984.

25 D. Li, X. Li and J. Gong, Chem. Rev., 2016, 116, 11529-11653.

26 S. Li and J. Gong, Chem. Soc. Rev., 2014, 43, 7245-7256.

27 E. T. Saw, U. Oemar, X. R. Tan, Y. Du, A. Borgna, K. Hidajat and S. Kawi, J. Catal., 2014, 314, 32-46.

28 S. Chen, L. Luo, Z. Jiang and W. Huang, ACS Catal., 2015, 5, 1653-1662.

29 H. Muroyama, S. Hano, T. Matsui and K. Eguchi, Catal. Today, 2010, 153, 133-135.

30 H. Muroyama, H. Asajima, S. Hano, T. Matsui and K. Eguchi, Appl. Catal., A, 2015, 489, 235-240.

31 J. Li, X. Liu, W. Zhan, Y. Guo, Y. Guo and G. Lu, Catal. Sci. Technol., 2016, 6, 897-907.

32 M. Zhao, M. Shen and J. Wang, J. Catal., 2007, 248, 258-267.

33 J.-R. Kim, W.-J. Myeong and S.-K. Ihm, Appl. Catal., B, 2007, 71, 57-63.

34 L. Katta, P. Sudarsanam, G. Thrimurthulu and B. M. Reddy, Appl. Catal., B, 2010, 101, 101-108.

35 B. Zhang, D. Li and X. Wang, Catal. Today, 2010, 158, 348353.

36 K. Harada, T. Oishi, S. Hamamoto and T. Ishihara, J. Phys. Chem. C, 2014, 118, 559-568.

37 B. M. Reddy, L. Katta and G. Thrimurthulu, Chem. Mater., 2010, 22, 467-475.
38 A. Bueno-López, K. Krishna, M. Makkee and J. A. Moulijn, J. Catal., 2005, 230, 237-248.

39 Z. Stansch, L. Mleczko and M. Baerns, Ind. Eng. Chem. Res., 1997, 36, 2568-2579.

40 M. Taniewski, A. Lachowicz, R. Lachowicz, D. Czechowicz and K. Skutil, Ind. Eng. Chem. Res., 1994, 33, 185-190.

41 D. Pakhare and J. Spivey, Chem. Soc. Rev., 2014, 43, 78137837.

42 S. Damyanova, B. Pawelec, K. Arishtirova, M. V. M. Huerta and J. L. G. Fierro, Appl. Catal., A, 2008, 337, 86-96.

43 F. ç. Larachi, J. Pierre, A. Adnot and A. Bernis, Appl. Surf. Sci., 2002, 195, 236-250.

44 R. Leppelt, B. Schumacher, V. Plzak, M. Kinne and R. J. Behm, J. Catal., 2006, 244, 137-152.

45 A. Karpenko, Y. Denkwitz, V. Plzak, J. Cai, R. Leppelt, B. Schumacher and R. J. Behm, Catal. Lett., 2007, 116, 105115.

46 C. Yang, X. Yu, S. Heißler, A. Nefedov, S. Colussi, J. Llorca, A. Trovarelli, Y. Wang and C. Wöll, Angew. Chem., Int. Ed., 2017, 56, 375-379.

47 S. Deshpande, S. Patil, S. V. Kuchibhatla and S. Seal, Appl. Phys. Lett., 2005, 87, 133113.

48 C. A. Orge, J. J. M. Órfão, M. F. R. Pereira, A. M. Duarte de Farias, R. C. R. Neto and M. A. Fraga, Appl. Catal., B, 2011, 103, 190-199.

49 C. Ho, J. C. Yu, T. Kwong, A. C. Mak and S. Lai, Chem. Mater., 2005, 17, 4514-4522.

50 B. Liu, Q. Li, X. Du, B. Liu, M. Yao, Z. Li, R. Liu, D. Liu, X. Zou, H. Lv, D. Li, B. Zou, T. Cui and G. Zou, J. Alloys Compd., 2011, 509, 6720-6724.

51 M. Sorescu, T. Xu, J. D. Burnett and J. A. Aitken, J. Mater. Sci., 2011, 46, 6709-6717.

52 E. M. Wilcox, G. W. Roberts and J. J. Spivey, Catal. Today, 2003, 88, 83-90.

53 B. Bachiller-Baeza, C. Mateos-Pedrero, M. A. Soria, A. Guerrero-Ruiz, U. Rodemerck and I. Rodríguez-Ramos, Appl. Catal., B, 2013, 129, 450-459.

54 S. J. Huang, A. B. Walters and M. A. Vannice, Appl. Catal., B, 2000, 26, 101-118.

55 M. P. Rosynek and D. T. Magnuson, J. Catal., 1977, 48, 417421.

56 L. M. Cornaglia, J. Múnera, S. Irusta and E. A. Lombardo, Appl. Catal., A, 2004, 263, 91-101.

57 B. M. Faroldi, J. F. Múnera and L. M. Cornaglia, Appl. Catal., B, 2014, 150-151, 126-137.

58 X. B. Wang, C. Song, K. W. Geng, F. Zeng and F. Pan, Appl. Surf. Sci., 2007, 253, 6905-6909.

59 Z.-Y. Pu, J.-Q. Lu, M.-F. Luo and Y.-L. Xie, J. Phys. Chem. C, 2007, 111, 18695-18702.

60 A. D. Liyanage, S. D. Perera, K. Tan, Y. Chabal and K. J. Balkus, ACS Catal., 2014, 4, 577-584.

61 J. Ni, L. Chen, J. Lin, M. K. Schreyer, Z. Wang and S. Kawi, Int. J. Hydrogen Energy, 2013, 38, 13631-13642.

62 M. M. Nair, S. Kaliaguine and F. Kleitz, ACS Catal., 2014, 4, 3837-3846.

63 H. Ma, L. Zeng, H. Tian, D. Li, X. Wang, X. Li and J. Gong, Appl. Catal., B, 2016, 181, 321-331. 
64 S. Valange, A. Beauchaud, J. Barrault, Z. Gabelica, M. Daturi and F. Can, J. Catal., 2007, 251, 113-122.

65 S. Gaur, D. J. Haynes and J. J. Spivey, Appl. Catal., A, 2011, 403, 142-151.

66 J. H. Scofield, J. Electron Spectrosc. Relat. Phenom., 1976, 8, 129-137.

67 G. Kresse and J. Furthmüller, Comput. Mater. Sci., 1996, 6, 15-50.
68 Z.-J. Zhao, A. Kulkarni, L. Vilella, J. K. Nørskov and F. Studt, ACS Catal., 2016, 6, 3760-3766.

69 G. Pacchioni, J. Chem. Phys., 2008, 128, 182505.

70 P. E. Blöchl, Phys. Rev. B: Condens. Matter Mater. Phys., 1994, 50, 17953-17979.

71 S. Fabris, S. de Gironcoli, S. Baroni, G. Vicario and G. Balducci, Phys. Rev. B: Condens. Matter Mater. Phys, 2005, 72, 237102. 